\title{
Bird Names and Folklore from the Emberá (Chocó) in Darién, Panamá
}

\author{
Stephanie C. Kane
}

Author Address: Department of International Studies, School of Global and International Studies, Indiana University, 355 North Jordan Avenue, Bloomington, IN 47405-1105 USA.

Email: stkane@indiana.edu

Received: July 15, 2014

Volume: 6:32-62

Published: June 15, 2015

C 2015 Society of Ethnobiology

\begin{abstract}
This paper presents data on folklore and names of birds collected among native speakers of Emberá in the moist tropical forests of Darién, Panamá. The naming data was collected by systematic elicitation of names from pictorial representations of birds. It is organized here to facilitate analysis of various aspects of folk taxonomy in relation to scientific taxonomy. Folklore about birds collected in natural contexts is also included to indicate the role of birds and their names in symbolic processes that exceed the limits of literal reference.
\end{abstract}

Keywords: Emberá (Chocó), Bird classification, Darién forest, Panama, Bird folklore

Supplementary Files available at ojs.ethnobiology.org/index.php/ebl.

\section{Introduction}

This paper presents data on names (see Appendix 1) and folklore (Appendix 2) of birds collected among native speakers of Emberá ${ }^{1}$ in the moist tropical forests of Darién, Panamá in 1984 and 1985.2 In most of Panama, the Emberá are popularly known as the Chocó, a name taken from the Department of Chocó in Colombia, from whence many crossed the low mountain range into the Darién to settle. The name Chocó also includes a sister linguistic group of the Emberá named the Wounaan, who live closely among them. The Catio and Chami are also closely related indigenous groups. The Emberá and Wounaan are principally distinguished by their languages, which are related (almost 50\% agreement of cognate roots) but mutually unintelligible (Loewen 1963a, b). Most speakers are bilingual in either Emberá or Wounaan and Spanish. Emberá and Wounaan use Spanish to speak to each other and to the ethnographer. In his early linguistic work in the Chocó River Basin, Loewen (1958:1) identifies nine Emberá and three Wounaan dialects based on phonological, morphological, and lexical features associated with particular localities. ${ }^{3}$ The bird name data presented here reflect variations derived from these differences in dialect and locality of origin.

The Emberá build open thatch-roofed homes on stilts along the many rivers. They hunt, fish, gather wild foods and medicines, and grow corn, rice, bananas, plantains, manioc, and medicinal plants (Kane 1995; Dalle and Potvin 2004). Traditionally, they live in fairly egalitarian, politically autonomous, extended family households dispersed along the rivers. However, under the mid-twentieth century push for rural development, the Emberá began concentrating riverine household sites into villages and electing representatives who became actors in regional and national politics. By this means, they worked to legally establish and to protect cultural and geographic autonomy and to receive government resources for, among other things, health clinics, and primary schools (Herlihy 1985, 2003; Kane 1994/2004; Cansarí 1996; Chapin 2001; Cahn 2004; Colin 2010).

This data was collected as a small part of a larger ethnographic research project on the cultural dimensions of village formation and national integration. 4 The project was carried out in two villages on two interior rivers. Avian data collection was carried out in the smaller and newer of the two, a village of only 10 households not far from what has since become the Darién Biosphere Reserve, National Park, and UNESCO World Heritage Site. The data provide documentary evidence of the linguistic and ethnobiological diversity of a unique, narrow stretch of tropical forest that bridges South and Central America at a time and place still relatively protected from the inexorable impact of regional deforestation. Bird habitat was still plentiful. Unlike the youngsters who learned Spanish in village schools, elders learned to speak Spanish through market contacts with nonindigenous people of Panama and Colombia. The 
villagers among whom this data was collected relied almost completely on the animals and plants of the riverine forest for subsistence and inspiration. Probably because of the intense violence in the region since the late 1980s, published ethnozoological research among the Emberá of Darién was and remains scarce. ${ }^{5}$ Indeed, to my knowledge, since the larger ethnographic project that provided a context for the collection of this avian data, there has been no in-depth ethnographic research published.

The naming data was collected by systematic elicitation from colored pictorial representations of birds. ${ }^{6}$ Except to share Emberá bird names, the elicitation groups used Spanish to communicate with the ethnographer. ${ }^{7}$ Data are organized to facilitate analysis of particular aspects of folk taxonomy such as contrast, level, and ranking of taxa; hierarchic inclusion and depth in taxonomic structures (Berlin 1992, Berlin 1976; Conklin 1969; Kay 1971); grading within categories (Kempton 1978; Lakoff 1972); taxonomic space (Hunn 1976) and comparison of folk and scientific taxonomies (Berlin et al. 1966; Berlin 1973). In this format, the data can be compared, contrasted or combined with other ethnobiological data.

In addition to the taxonomic data, which were elicited in contexts that were contrived by me, folkloric data, collected in more or less natural contexts, are also presented here. The folkloric data provides examples of the metaphorical connections between names and their referents (Bean 1975; Dougherty 1982; Johnson 1974; Rosaldo 1972). My interlocutors shared the folklore in the form of stories, conversations, and reflections on avian life happening around us as, for example, we canoed on the river, rested from cleaning bush, walked through the forest, or sat by the hearth. My interlocutors also contributed folklore in the context of the group elicitation sessions. To reflect the two distinct modalities of data collection and the style in which the data were conveyed, the ethnographer's voice shifts as I move between taxonomic and folkloric sections.

\section{Elicitation Procedures}

I presented 32 color plates from Ridgely's (1976) Birds of Panama, in order of their appearance in the book, to nine independent groups of people in their homes, or in one case, in a work setting. The design was opportunistic; that is, I took advantage of situations conducive to data collection and did not attempt to control group composition. The aim was to collect data in a manner that did not disrupt everyday life. As an interesting visual object, once introduced and held in my hands, the book became a conversation piece. Its well-drafted images of species that varied beautifully in form and color made the page-layout itself a pleasurable and stimulating elicitation device. The origin of the book and the unreadable text within it clearly signaled its foreignness, but the images it contained were legible and familiar, and so the book worked well as an elicitation tool. It was a well-received artifact that promoted and coordinated sociality for about an hour or two per session.

Each set represents a consensus elicitation from two to ten people. They were a mix of generation and gender although there was no group that included only children or youths. Through discussion each group would decide on one name for each bird they identified; they took it upon themselves not to present multiple names. Where several people were present one or two more knowledgeable elders dominated the discussion. Other than deference to elders with more knowledge, there were no noticeable differences in power or authority that affected the outcome of consensus.

Bird names are listed here in such a way that the relationship between Emberá and scientific names stands out. Each Emberá name is listed together with the plate and identification number of each species designated, the corresponding scientific name, the general common name in English, a list showing which of the nine elicitation groups (here represented as capital letters "A" through "I") make the identification and the total number of groups that make the identification as an expression of inter-group consensus. ${ }^{8}$

There are various limitations to this kind of elicitation procedure. Information on one plate could inform another, e.g. where an early identification was unclear, a later more typical example might clarify. As the elicitation process proceeded, informants had more information at their disposal with which to make a judgment and therefore the level of accuracy probably is not consistent. On the other hand, in some cases where scientific genera happened to be separated on non-consecutive plates, informants did identify them with the same Emberá name, indicating that they could transcend the restrictions imposed by book order (e.g. the genus Cranioleuca on Plates 8 and 14 , both identified as jorójorô $)$. In addition, because 
each group had more than one person in it (a factor shaped by the social conditions of fieldwork among extended families), the nine elicitation groups are more diverse then nine single informants would be. Furthermore, because names were elicited from a printed page rather than from birds in their natural habitat, certain physical criteria tended to dominate the identification process, e.g. beak type was a more distinguishable feature than variation in size and behavioral and functional criteria were only available in the form of memory associations.

\section{Presentation of Taxonomic Data}

Each category identified by an Emberá name that is a primary lexeme (one which cannot be translated directly) is listed in alphabetical order in Appendix 1. Names which combine a lexeme with a modifier are listed under the main lexeme (e.g. ansabidá [kingfisher] is the lexeme listed alphabetically under which will appear ansabidá chikaibéa [little kingfisher] and meabémaansabidá [forest kingfisher]). Within that ordering of categories, the different scientific species identified by the same name are listed from highest consensus to lowest consensus. Where the consensus ratings are equal, they are listed in the order in which they appear in the book. Where the relationship between one lexeme and another is not manifested in the form of the name, but is commented on by a speaker, the more general name is listed in curly brackets under specific name (e.g. chilingó [cacique] is a kind of kumbarrá [a category including caciques, oropendolas, and antbirds]). In compound names in which one of the names may or may not be spoken, or in names which may or may not have particular endings, straight brackets [] will appear around the optional segment. ${ }^{10}$

\section{Notes on Emberá-English Translation}

The Emberá language has 12 vowels: a, e, i, $\Lambda, \mathrm{o}, \mathrm{u}$ (pronounced as in Spanish except for the $/ \Lambda /$ which is somewhere between $i$ and $u$ ) and the same sounds nasalized: $\tilde{a}, \tilde{e}, \tilde{1}, \lambda$, õ, ũ. The consonants are pronounced the same as in Spanish, i.e. $j$ is pronounced as the English $\mathrm{h}$; dz is pronounced as English $\mathrm{j}$. Where name-segments are emphasized with a stop, this is indicated by an apostrophe (') after the segment.

As mentioned above, there are 12 dialects in the language of Emberá corresponding to 12 geographic areas in Colombia from whence the Emberá came before they migrated to Panama (Loewen 1958).
Dialectal variation is reflected both at the lexical and phonological levels. I have indicated phonological variation of particular names with the superscript "v" and list the variants at the end of the taxonomy data. Lack of accurate migration data on all informants and the methods of elicitation used precludes analysis of nomenclature in respect to dialects.

Where names are combinations of words or morphemes, part or all of which I can translate, I set these off from each other by a dash and indicate a dictionary listing with a superscript "d". These translations appear in the supplementary file linked to this document (Supplementary Table 1). I have only included Spanish loan words when there is no Emberá name corresponding to the same category. These are noted with the superscript "Sp."

\section{Note on the Classification of Emberá and Scien- tific Bird Names}

There are interesting comparisons to be made between the folk and scientific taxonomies (Appendix 1). While in some cases one Emberá name exactly or almost exactly corresponds to one scientific genus (e.g. kokarrá and the genus Odontophorus, chákoro and the genus Icterus), in most cases there is a different kind of "fit." So, for example, the Emberá, like English speakers, have only one name for all hummingbirds, while the scientific taxonomy breaks these down into 35 genera. Clearly, the physical attributes necessary for systematizing these birds from an evolutionary point of view are not relevant to Emberá speakers. There are cases, however, in which the Emberá taxon is more elaborated than the scientific. For example, there is a general name karé and four specific names that correspond to a single scientific genus Amazona. For the Emberá, this kind of bird is distinctive not only because of its bright plumage and noisy behavior, but because it is also a source of food. There is also a varying relation between the most typical species representing a group of genera that together constitute a taxon and the size of the taxon. So, for example, Pulsatrix perspicillata Latham Strigidae is the species of owl that most represents "owlness" to the Emberá and the name for that species, bomborra, includes eight genera within its reference. While a name like jorójoró, represented with best consensus by Taraba major Vieillot Thamnophilidae includes 27 genera within its reference. All these variations of fit between Emberá and scientific taxonomies of birds can be considered in relation to other folk taxonomies of birds as well as folk taxonomies of other biological 
classes, in order to develop a cross-cultural understanding of the principles of category formation and more generally how human beings think about the natural world.

Folkloric examples presented in Appendix 2 were collected as they emerged spontaneously in the context of everyday life and suggest the important role that birds play in the encoding of cosmological as well as social and utilitarian thought. The songs and calls of particular bird species are located between the invisible and the human worlds as they inform people of new birth and impending death. Because songs and calls depart and are distinct from the avian bodies that produce them, they can travel across the space of the imagination as well as physical space. In Emberá cosmology, an otherworld accompanies the mundane world. Birds symbolically mediate the two worlds. They have the power to tell about matters as small as the time of day and as great as the events that happened when the world changed. Indeed, before the world changed, animals were people. And, although this happened in ancient times, the world could change back any day. So say the Emberá when they observe the widening rivers, the atypical flooding patterns and the long dry seasons that are accompanying the transformation of the downstream forests into fields and pastures.

\section{Conclusion}

Taxonomic and folkloric modes of knowledge, together, suggest the significant role that birds play in Emberá life. They illuminate relationships between biodiversity and cross-cultural bird knowledge in the lowland riverine tropical forest. When geopolitical conditions allow future ethnobiologists to do research in the interior of the Darién, whether inside or outside the biosphere reserve, the data presented here can provide a baseline for comparison and departure point for conversation. Further study will not only lead to a better understanding of how the Emberá enroll nature in their conceptions of a mythic universe in which animals are communicating co-spirits, but will also lead to a better understanding of Emberá thoughts about their place in the dynamic environmental history of the Darién.

\section{Acknowledgements}

My thanks to the Emberá people who accepted and protected me and who generously shared their knowledge of the forest. I thank Larry Gilbert for introducing me to field biology and rainforest logistics, Joel Sherzer for teaching me indigenous language transcription skills, Brian Stross for introducing me to ethnosemantics and encouraging me to publish these data, Harriet Klein for reading earlier versions of this manuscript, and Semantha Bertram and Jonathan Dombrosky for assistance with data input and formatting.

\section{Declarations}

Permissions: None declared.

Sources of Funding: My 1984-1985 dissertation fieldwork with the Emberá was funded by a fellowship from the Organization of American States and the Institute of Latin American Studies, University of Texas at Austin. Conflicts of Interest: None declared.

\section{References}

Aguirre Licht, D. 2006. Choco Language. In Encyclopedia of Language and Linguistics, $2^{\text {nd }}$ edition, edited by K. Brown, pp. 367-381. Elsevier, Oxford.

Bean, S. 1975. Referential and Indexical Meanings of Amma in Kannada: Mother, Woman, Goddess, Pox, and Help! Journal of Anthropological Research 31:313330.

Berlin, B. 1973. Folk Systematics in Relation to Biological Classification and Nomenclature. Annual Review of Ecology and Systematics 4:259-271.

Berlin, B. 1992. Ethnobiological Classification: Principles of Categorization of Plants and Animals in Traditional Societies. Princeton University Press, Princeton, NJ.

Berlin, B. 1976. The Concept of Rank in Ethnobiological Classification: Some Evidence from Aguaruna Folk Botany. American Ethnologist 3:381-399.

Berlin, B., D. Breedlove and P. Raven. 1966. Folk Taxonomies and Biological Classification. Science 154:273-275. Doi: 10.1126/science.154.3746.273.

Bittner, K. 2003. Diversity of Mammals and their Uses and Perceptions by the Embera of Maje, Bayano Region, Panama. School for International Training, Panama.

Cahn, D. E. 2004. Homeless for Generations: Land Rights for the Chocoe Indians from Mogue, Panama. Fordham International Law Journal 28:232290.

Cansarí, R. 1996. The Scientific Community and the Indigenous Emberá Community of Panama. In Protecting Biological Diversity: Roles and Responsibilities, edited by M. Kranzel, G. Seutin and C. Potvin, pp. 26-40. McGill-Queen's University Press, Quebec. 
Chapin, M. and B. Threlkeld. 2001. Indigenous Landscapes: A Study in Ethnocartography. Center for the Support of Native Lands, Washington, DC.

Colin, F. L. 2010. "Nosotros no Solamente Podemos Vivir de Cultura": Identity, Nature, and Power in the Comarca Emberá of Eastern Panama. Unpublished Doctoral Dissertation, Carlton University.

Conklin, H. 1962. Lexicographical Treatment of Folk Taxonomies. In Problems in Lexicography, edited by F.W. Householder and S. Saporta, pp. 119-142. Indiana University Research Center in Anthropology, Folklore, and Linguistics, Bloomington, IN.

Crandell, R., ed. 2008. Emberá Stories of Panama. Translated by Rogelio Cansarí. Rainforest Press.

Dalle, S.P. and C. Potvin. 2004. Conservation of Useful Plants: An Evaluation of Local Priorities from Two Indigenous Communities in Eastern Panama. Economic Botany 58:38-57.

Dougherty, J. and C. Keller. 1982. Taskonomy: A Practical Approach to Knowledge Structures. American Ethnologist 9:763-774.

Drewal, H. J., ed. 2008. Sacred Waters: Arts for Mami Wata and Other Divinities in Africa and the Diaspora. Indiana University Press, Bloomington, IN.

Herlihy, P. 1985. Settlement and Subsistence Change among the Chocó Indians of the Darién Province, Eastern Panama: An Overview. Cultural Survival Quarterly 9:43-45.

Herlihy, P. 2003. Participatory Research Mapping of Indigenous Lands in Darien, Panama. Human Organization 62:315-331.

Hunn, E. 1976. Toward a Perceptual Model of Folk Biological Classification. American Ethnologist 3:508524.

Johnson, A. 1974. Ethnoecology and Planting Practices in a Swidden Agricultural System. American Ethnologist 1:87-101.

Kane, S. C. [1994] 2004. The Phantom Gringo Boat: Shamanic Discourse and Development in Panama. Smithsonian Institution Press, Washington D.C.; Second Edition. Cybereditions, Rochester, MN.

Kane, S. C. 1995. Emberá (Chocó) Medicinal Plant Use: Implications for Planning the Biosphere Reserve in Darién, Panama. In Yearbook for Ethnomedicine and the Study of Consciousness, No. 4, edited by
C. Rätsch and J. Baker, pp. 185-206. Verlag für Wissenschaft und Bildung, Berlin, Germany.

Kay, P. 1971. Taxonomy and Semantic Contrast. Language 47:866-887.

Kempton, W. 1978. Category Grading and Taxonomic Relation: A Mug is a Sort of Cup. American Ethnologist 5:44-65.

Lakoff, G. 1973. Hedges: A Study of Meaning Criteria and the Logic of Fuzzy Concepts. Journal of Philosophical Logic 2:458-508.

Loewen, J. 1958. An Introduction to Epera Speech: Sambú dialect. Ph.D. dissertation. Interdepartmental Linguistics. University of Washington, Seattle, WA.

Loewen, J. 1963a. Chocó 1: Introduction and Bibliography. International Journal of American Linguistics 29:239-263.

Loewen, J. 1963b. Chocó 2: Phonological Problems. International Journal of American Linguistics 29:357-371.

Racero-Casarrubia, J. A., C. C. Vidal and O. D. Ruiz. 2008. Percepción y Patrones de Uso de la Fauna Silvestre en Comunidades Indígenas Emberá-Katíos de la Cuenca del Río San Jorge, Zona Amortiguadora de PNN - Paramillo. Revista de Estudios Sociales 31:118-131.

Ridgely, R. 1976. A Guide to the Birds of Panama. Princeton University Press, Princeton, NJ.

Rosaldo, M. 1972. Metaphors of Folk Classification. Southwestern Journal of Anthropology 28:83-99.

Runk, J. V., M. Martínez Mauri, B. Quintero Sánchez and J. Sarsaneda del Cid, eds. 2011. Pueblos Indígenas de Panamá: Una Bibliografía. Acción Cultural Ngóbe, Panama.

Sara, S. I. 2001. A Tri-lingual Dictionary of EmberáSpanish-English. Lincom, München.

Supplementary Files are linked to the online version of the paper at ojs.ethnobiology.org/index.php/ebl.

\section{Biosketch}

Stephanie C. Kane is a cultural anthropologist and Professor in the Department of International Studies at Indiana University. She is the author of The Phantom Gringo Boat, AIDS Alibis, and Where Rivers Meet the Sea.

\section{Notes}

${ }^{1}$ Readers may view images of the Emberá in the 
Darién forest by visiting the Indiana University Image Collections Online.

${ }^{2}$ For in-depth ethnography of the Emberá in the Darién see Kane 1994/2004. For Emberá medicinal plants see Kane 1995. For Emberá folktales see Crandell 2008. For a comprehensive bibliographic index of writings on the indigenous people of Panamasee Runk et al. 2011:77-162.

${ }^{3}$ For recent linguistic research see Sara 2001 and Aguirre Licht 2006. For many other sources see Runk et al. 2011:77-162.

${ }^{4}$ As an ecologist with a specialty in tropical forest zoology at the Masters level I keep my interest alive through collection of ethnobiological data in the course of larger holistic ethnographic projects.

${ }^{5}$ For more recent ethnozoological research in the region outside the Darién see Bittner 2003, Bejarano et al. 2004 and Racero-Casarrubia et al. 2008.

${ }^{6}$ I received permission from the First Cacique of the Emberá to do ethnographic research in two specific villages. I also received permission from the Universi- ty of Texas IRB to do ethnographic research among the Emberá of Darién.

${ }^{7}$ I was trained in the transcription of Central and South American indigenous languages. As part of my larger project I was working with an Emberá youth to record and transcribe Emberá myths and folktales.

8 Since Ridgely's (1976) book, authorities have changes some species names. The Appendix reflects current usage.

${ }^{9}$ For orthography and transcription see Note on Language below.

${ }^{10}$ To prioritize the legibility of consensus ratings in Appendix 1, scientific and popular bird names are listed only in the main category for each Emberá bird name. Genus and species names are left blank in the subcategories. Wherever there is a subcategory blank, the key plate/image \# indicates which genus and species name from the main list is relevant. For English popular names, wherever there is a blank, readers should apply whichever name is listed most directly above it. 
(f) Ethnobiolocy LetTers Data, Methods \& Taxonomies

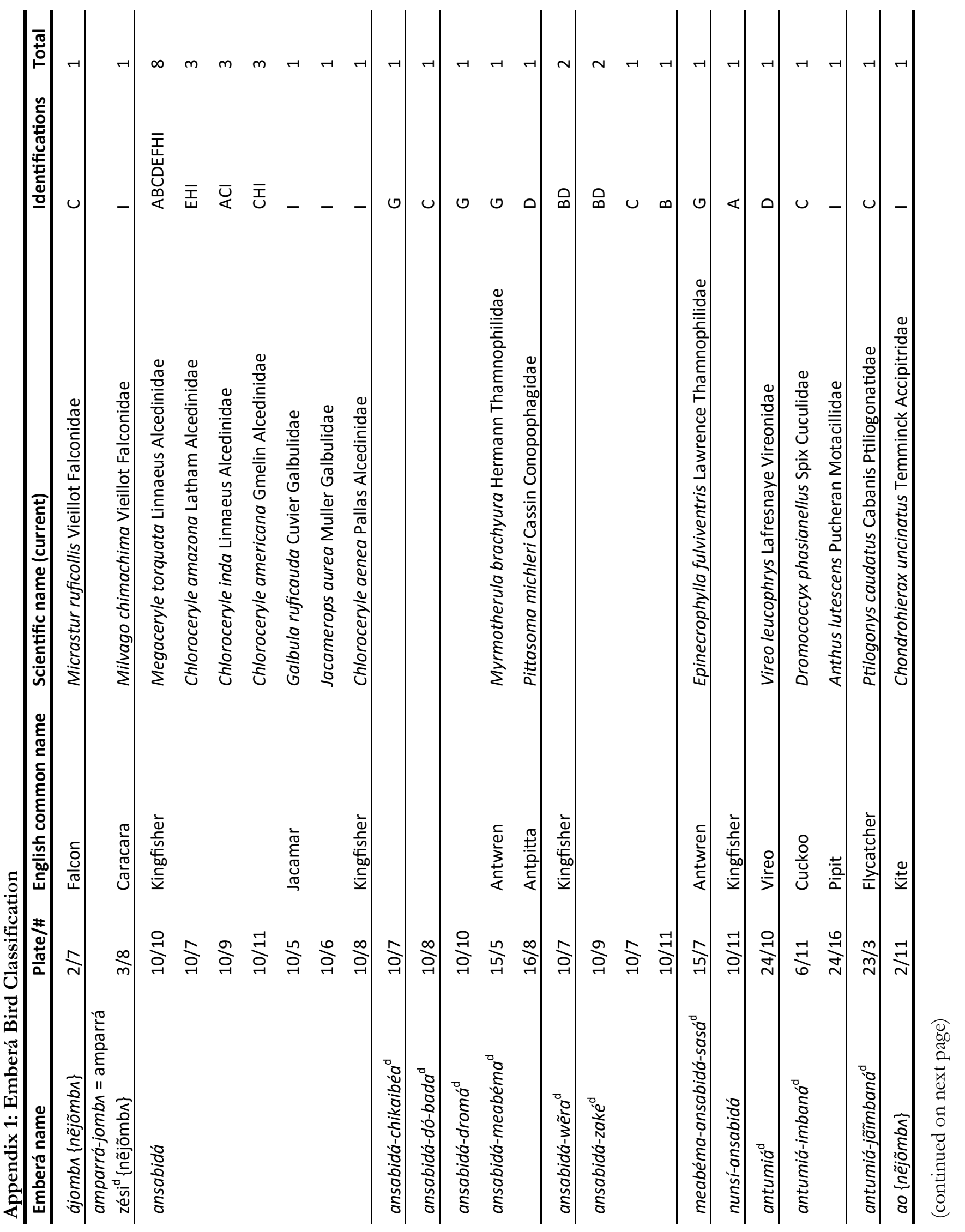

Ethnobiology Letters. 2015. 6:32-62. DOI: 10.14237/ebl.6.1.2015.226. 
fif Ethnobiolocy Letters Data, Methods \& Taxonomies

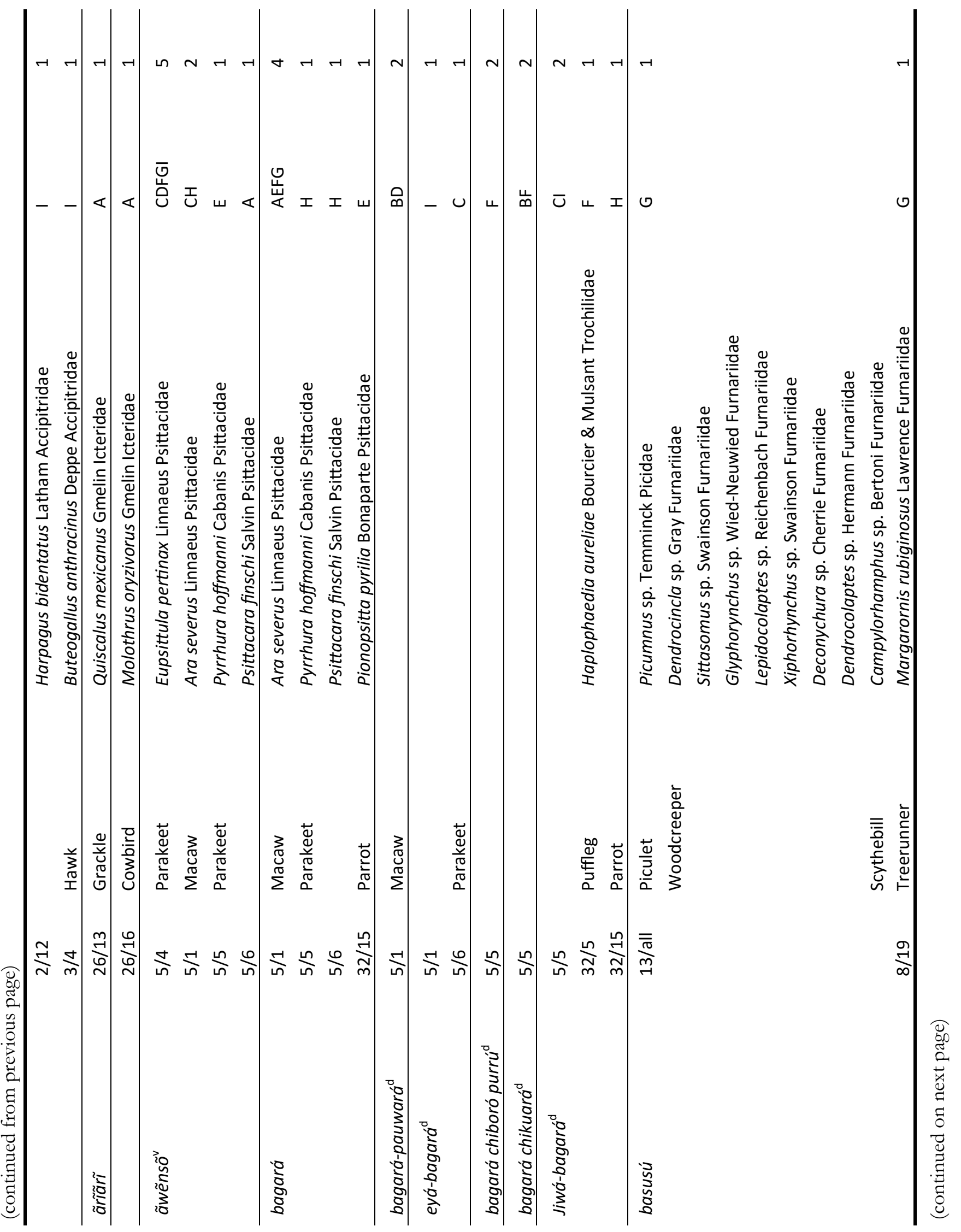

Ethnobiology Letters. 2015. 6:32-62. DOI: 10.14237/ebl.6.1.2015.226. 
fif Ethnobiolocy Letters Data, Methods \& Taxonomies

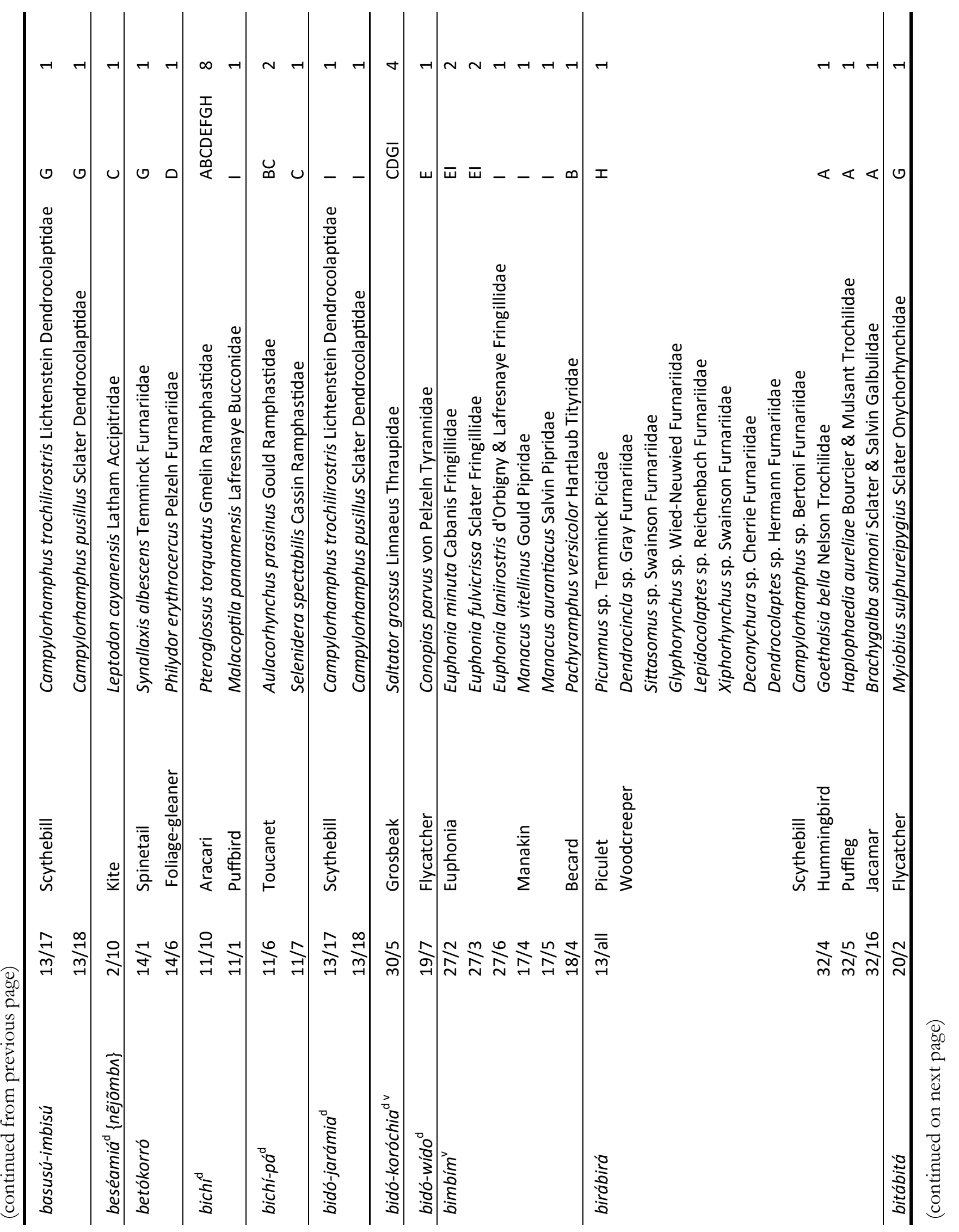

Ethnobiology Letters. 2015. 6:32-62. DOI: 10.14237/ebl.6.1.2015.226. 
(f) EthNobiology Letters Data, Methods \& Taxonomies

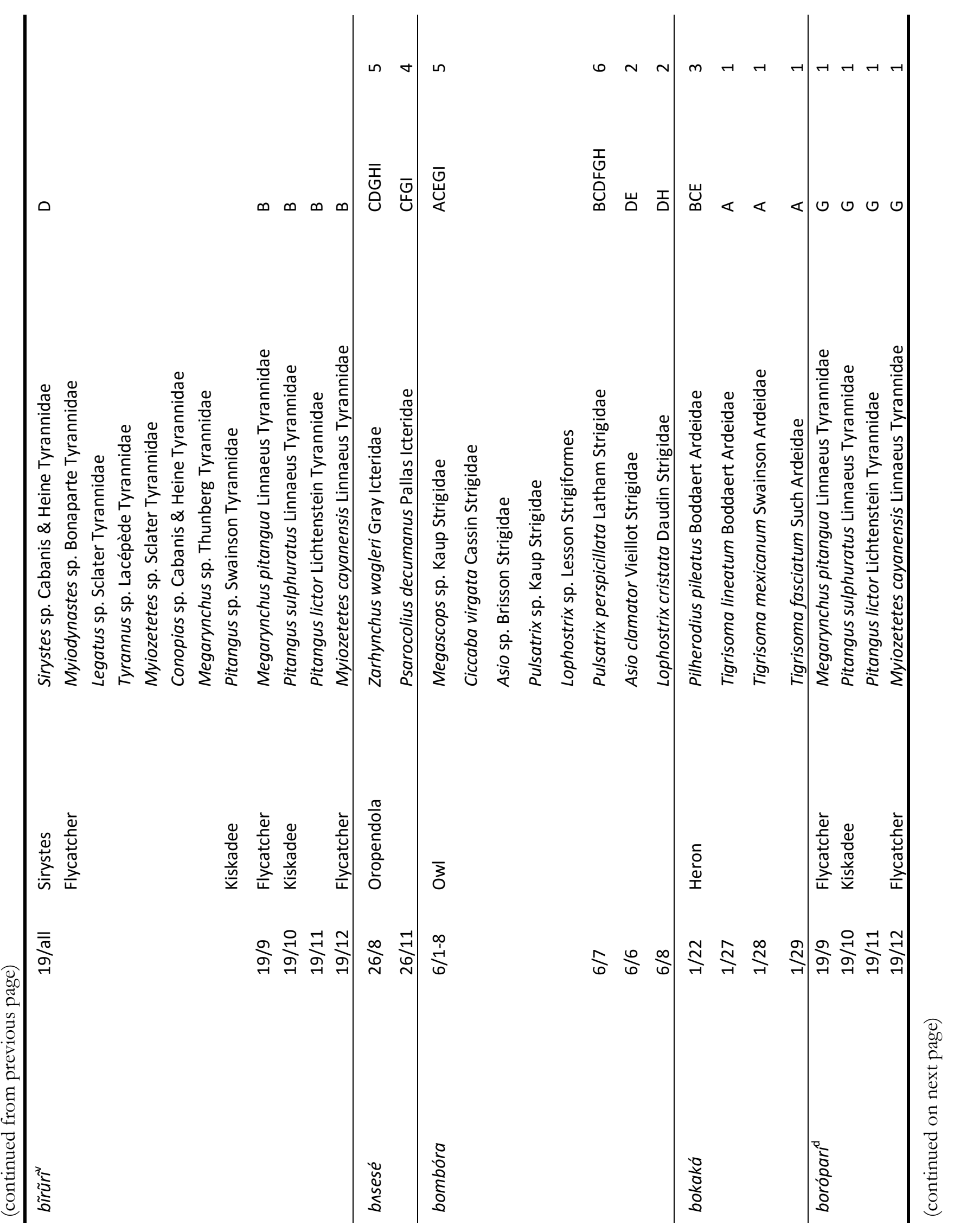

Ethnobiology Letters. 2015. 6:32-62. DOI: 10.14237/ebl.6.1.2015.226. 
fif Ethnobiolocy Letters Data, Methods \& Taxonomies

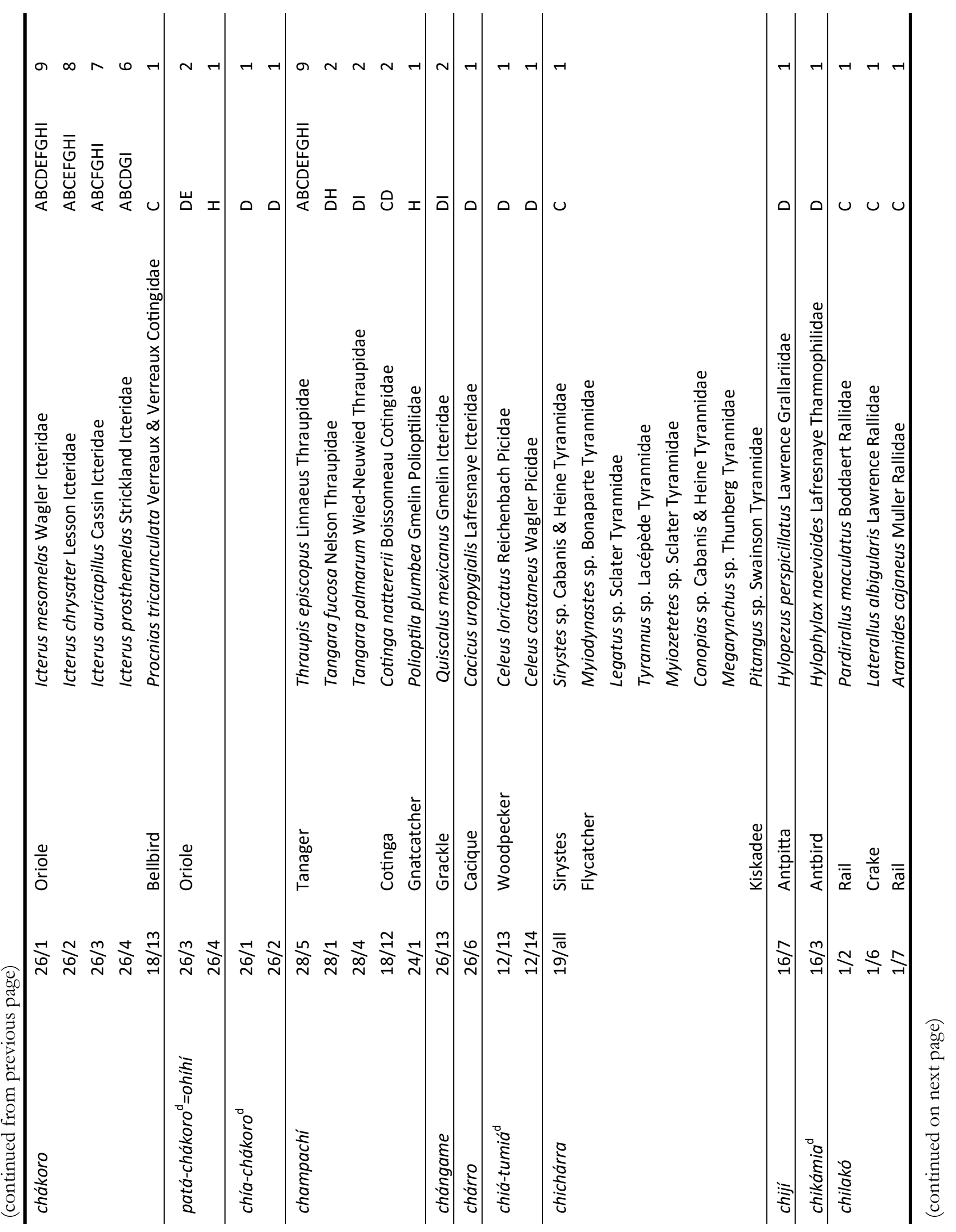

Ethnobiology Letters. 2015. 6:32-62. DOI: 10.14237/ebl.6.1.2015.226. 
fif Ethnobiolocy Letters Data, Methods \& Taxonomies

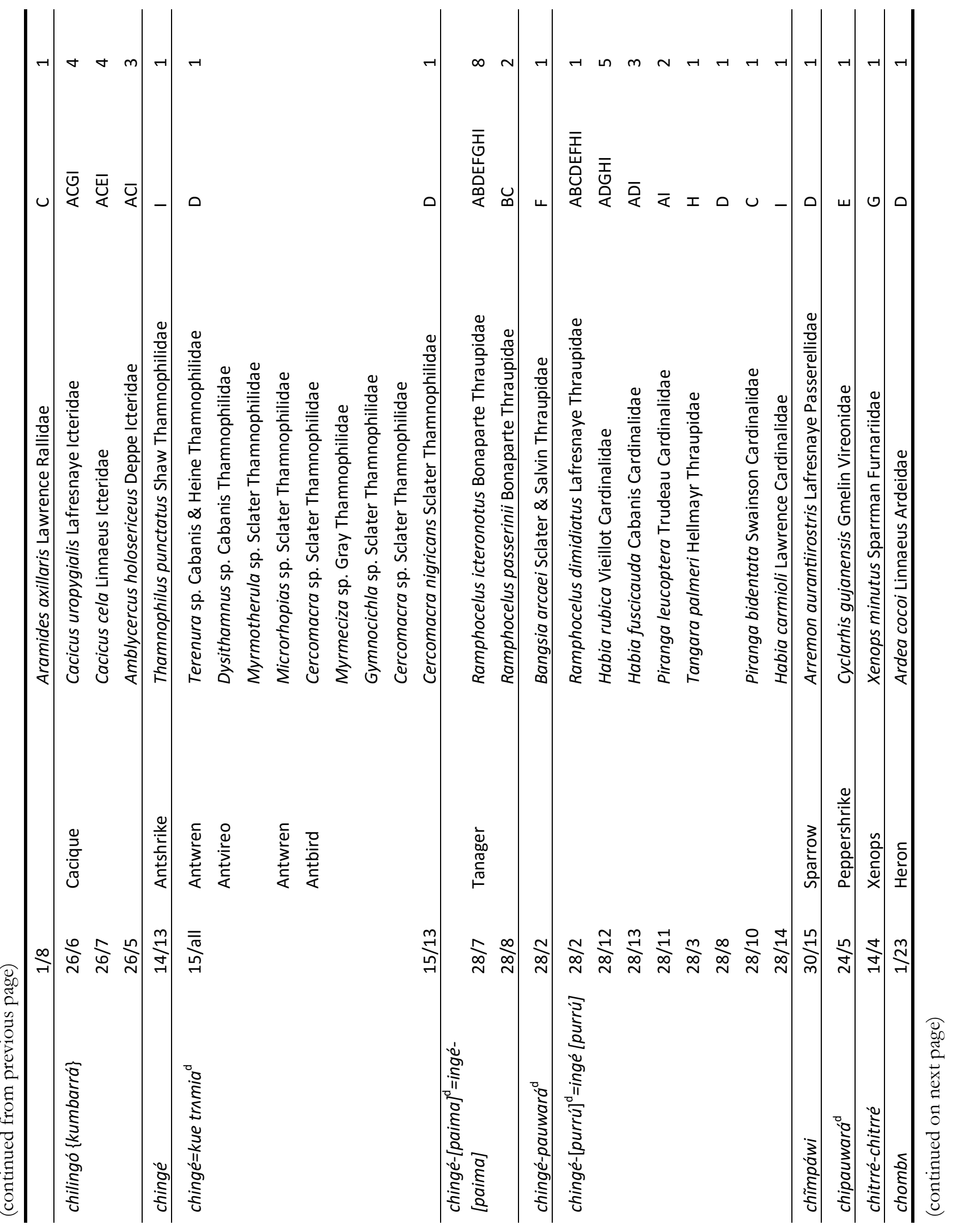

Ethnobiology Letters. 2015. 6:32-62. DOI: 10.14237/ebl.6.1.2015.226. 
fif Ethnobiolocy Letters Data, Methods \& Taxonomies

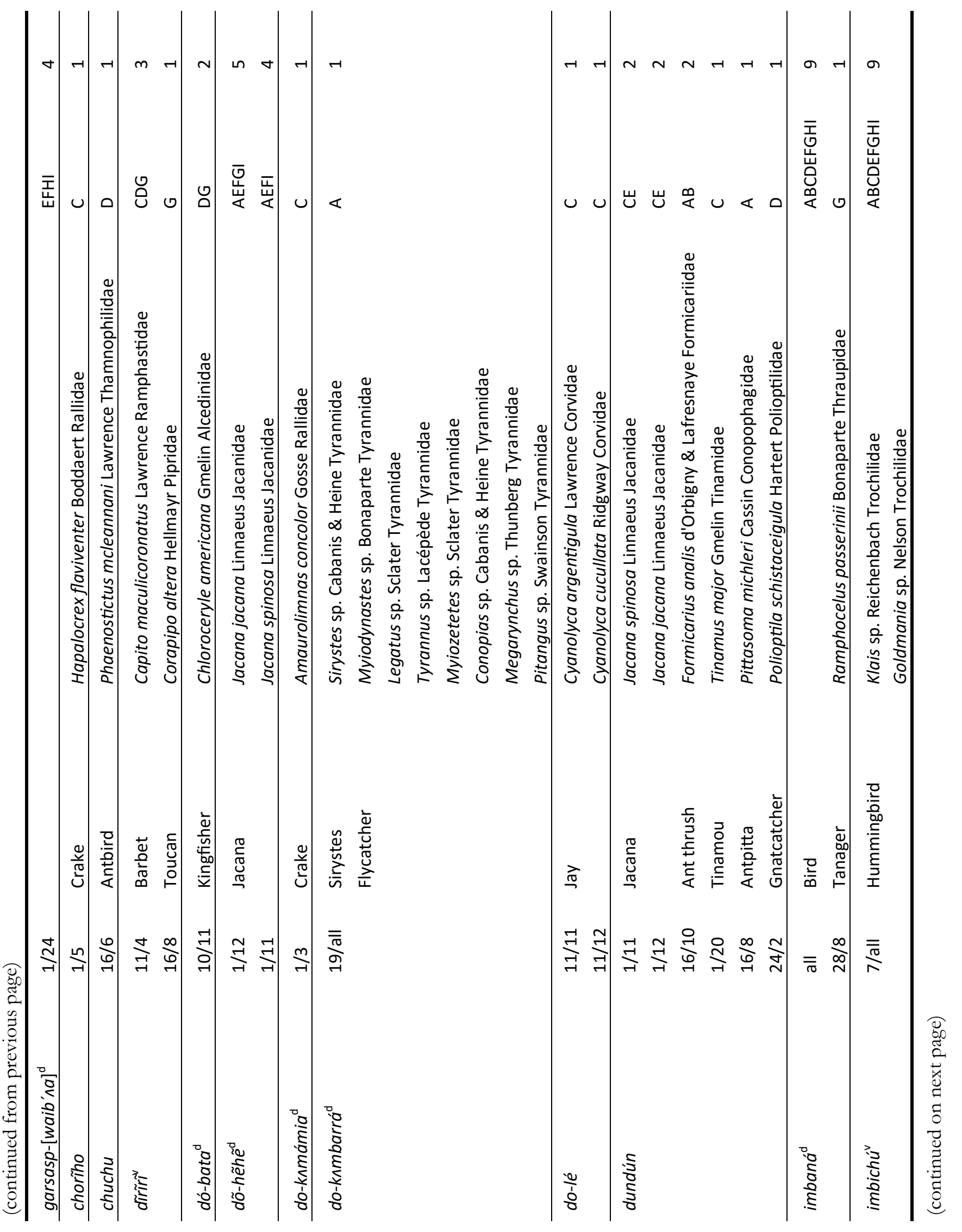

Ethnobiology Letters. 2015. 6:32-62. DOI: 10.14237/ebl.6.1.2015.226. 


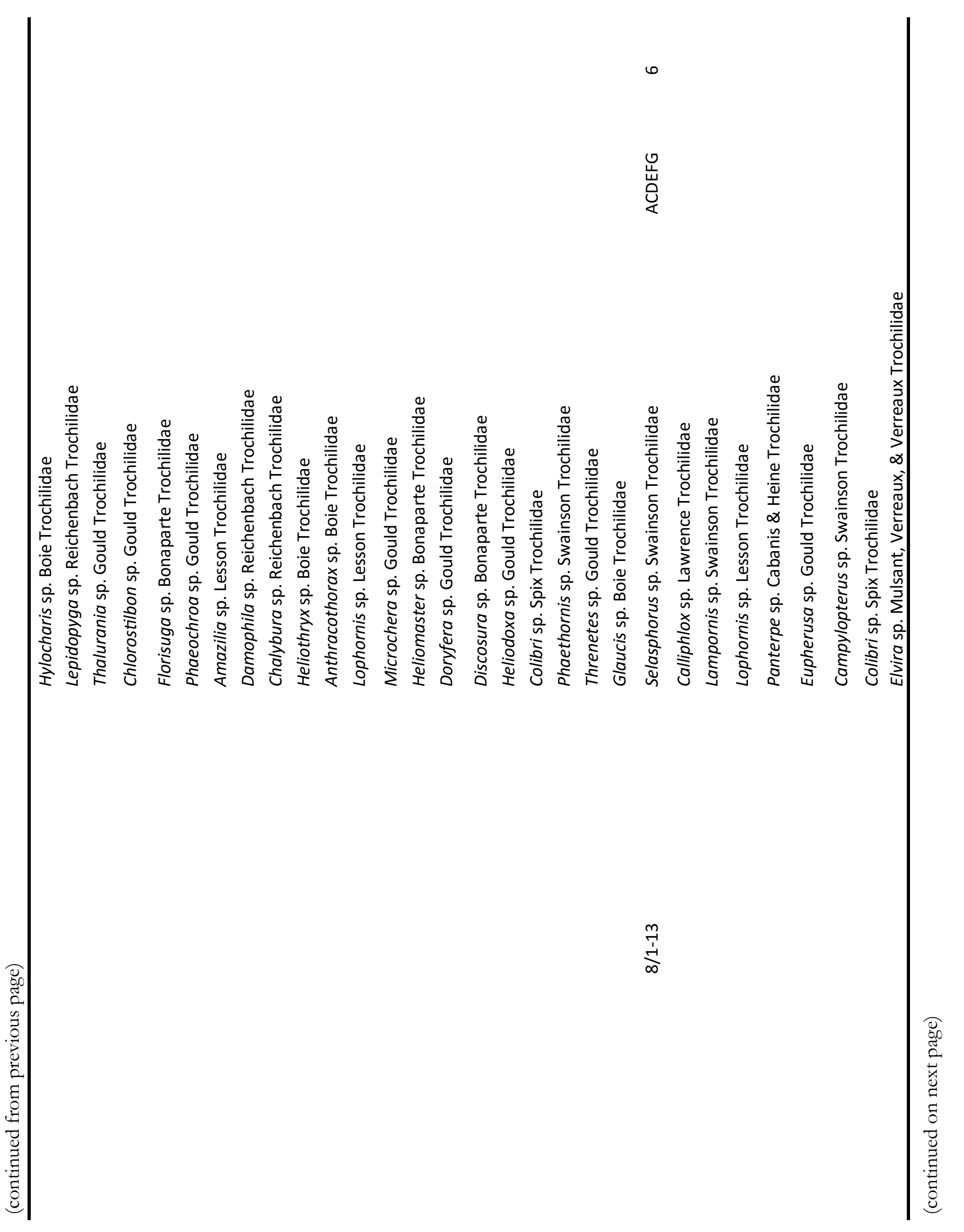

Ethnobiology Letters. 2015. 6:32-62. DOI: 10.14237/ebl.6.1.2015.226. 
(f) Ethnobiolocy LetTers Data, Methods \& Taxonomies

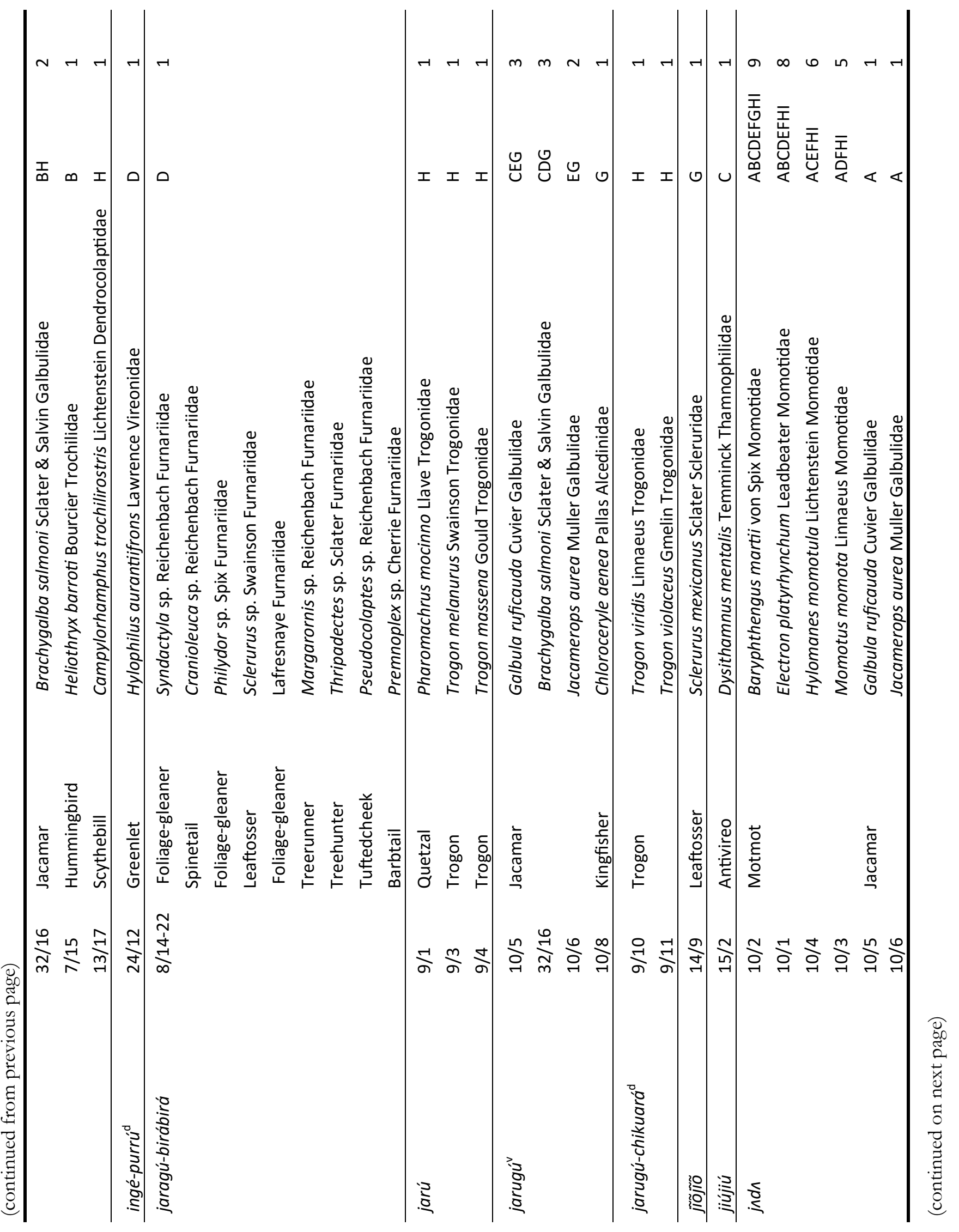

Ethnobiology Letters. 2015. 6:32-62. DOI: 10.14237/ebl.6.1.2015.226. 
fif EthNOBIOLOGY LetTers Data, Methods \& Taxonomies

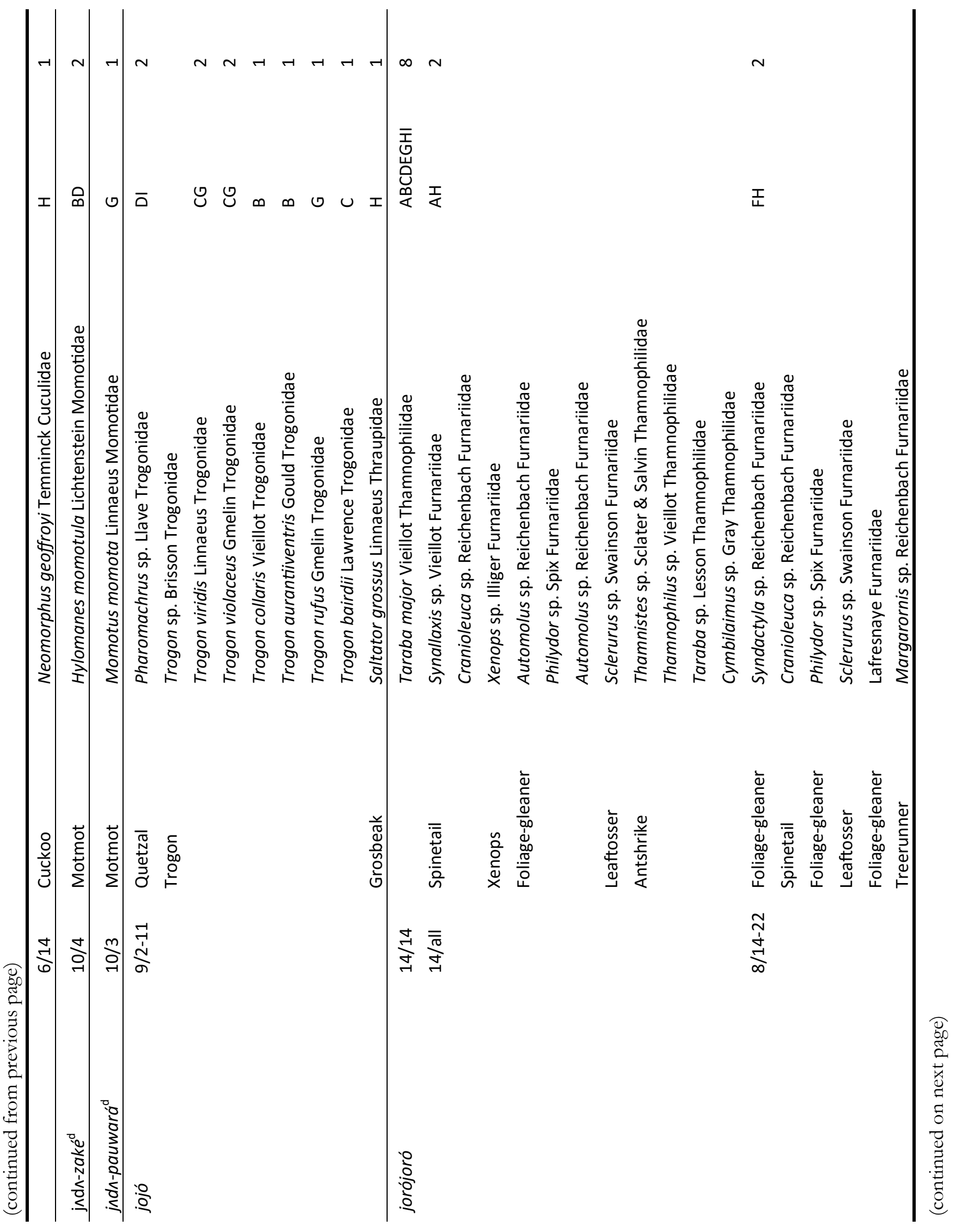

Ethnobiology Letters. 2015. 6:32-62. DOI: 10.14237/ebl.6.1.2015.226. 
(f) EthnObiolocy LetTers Data, Methods \& Taxonomies

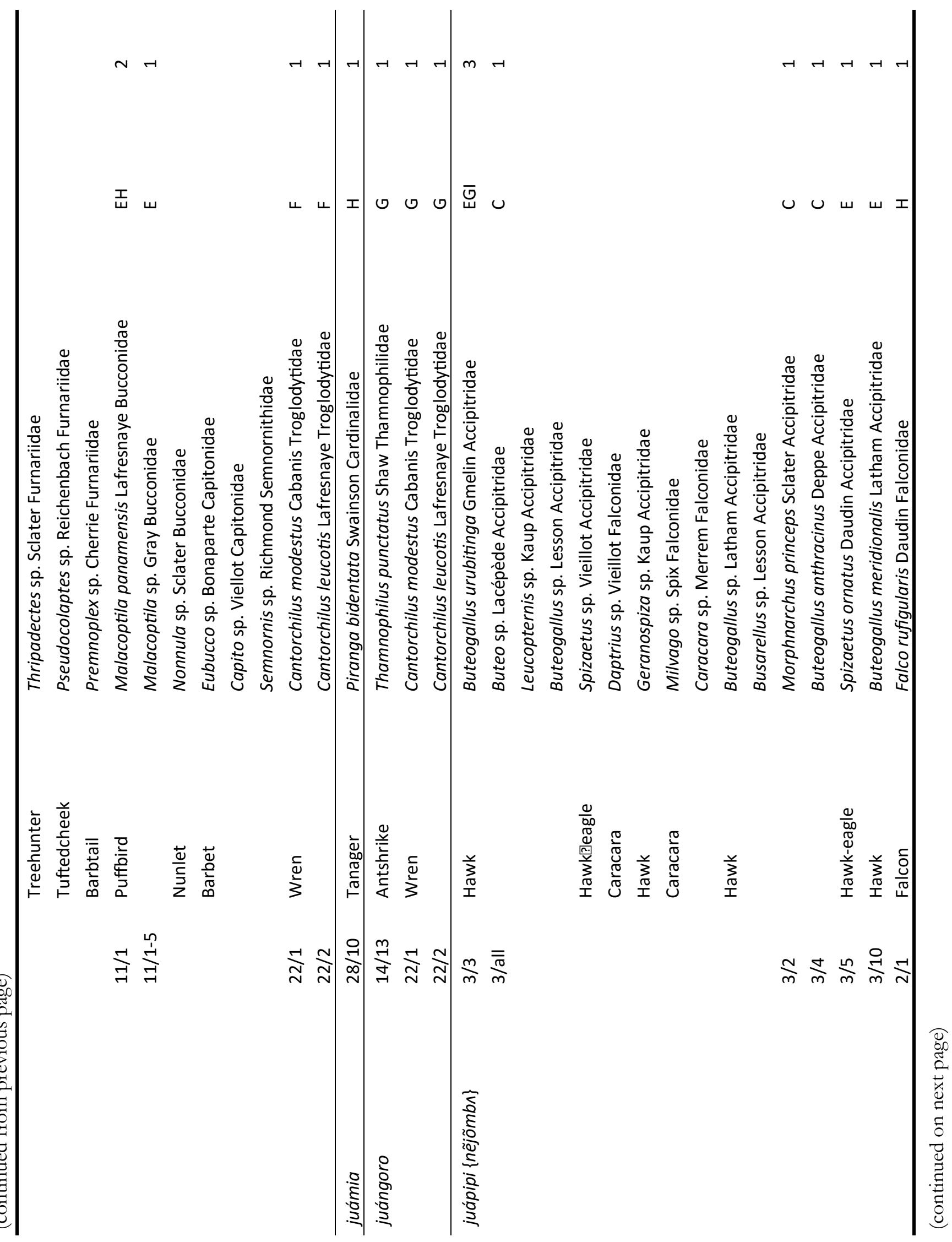

Ethnobiology Letters. 2015. 6:32-62. DOI: 10.14237/ebl.6.1.2015.226. 
(f) Ethnobiology Letters Data, Methods \& Taxonomies



Ethnobiology Letters. 2015. 6:32-62. DOI: 10.14237/ebl.6.1.2015.226. 
fif Ethnobiolocy Letters Data, Methods \& Taxonomies

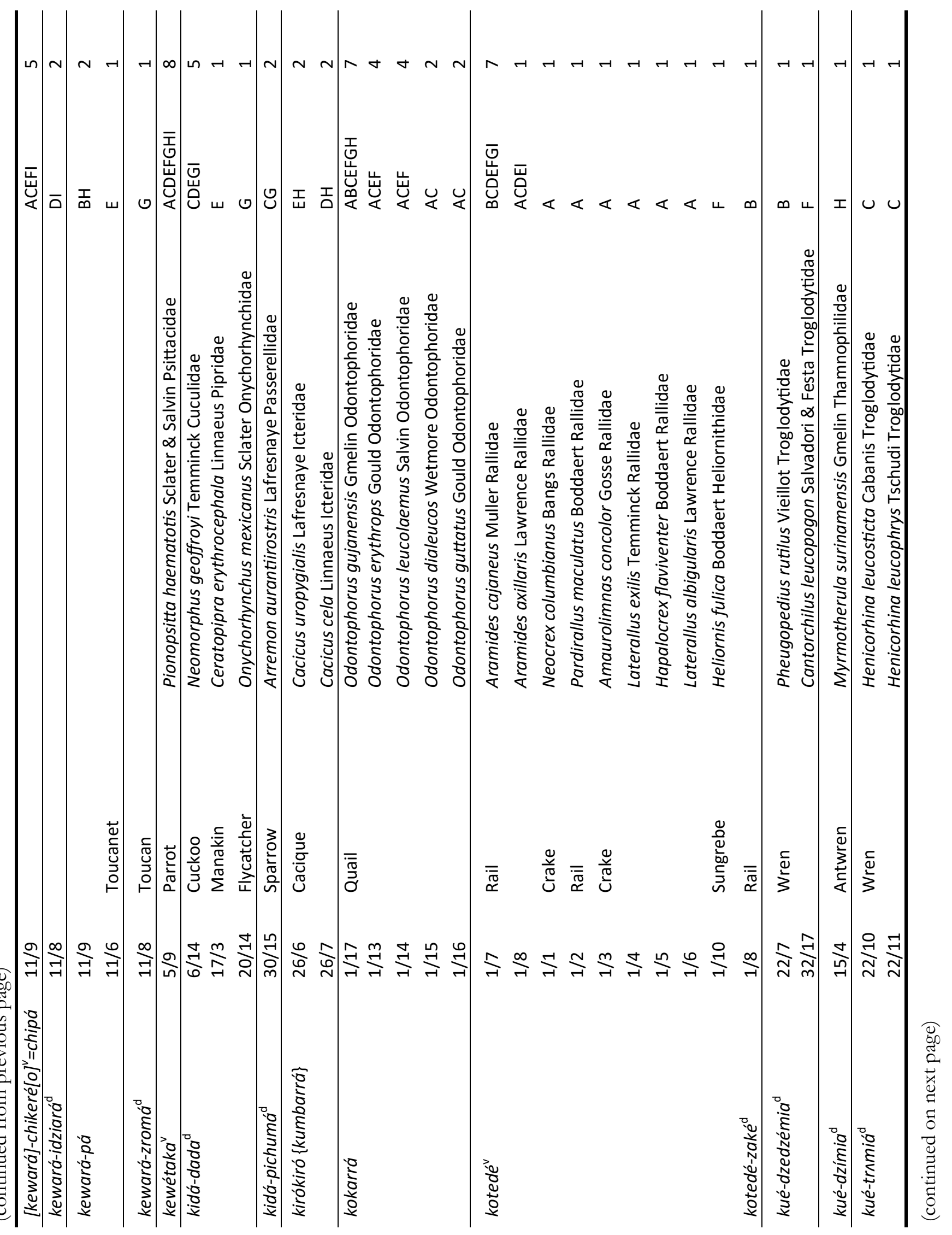

Ethnobiology Letters. 2015. 6:32-62. DOI: 10.14237/ebl.6.1.2015.226. 
(f) EthNobiology Letters Data, Methods \& Taxonomies

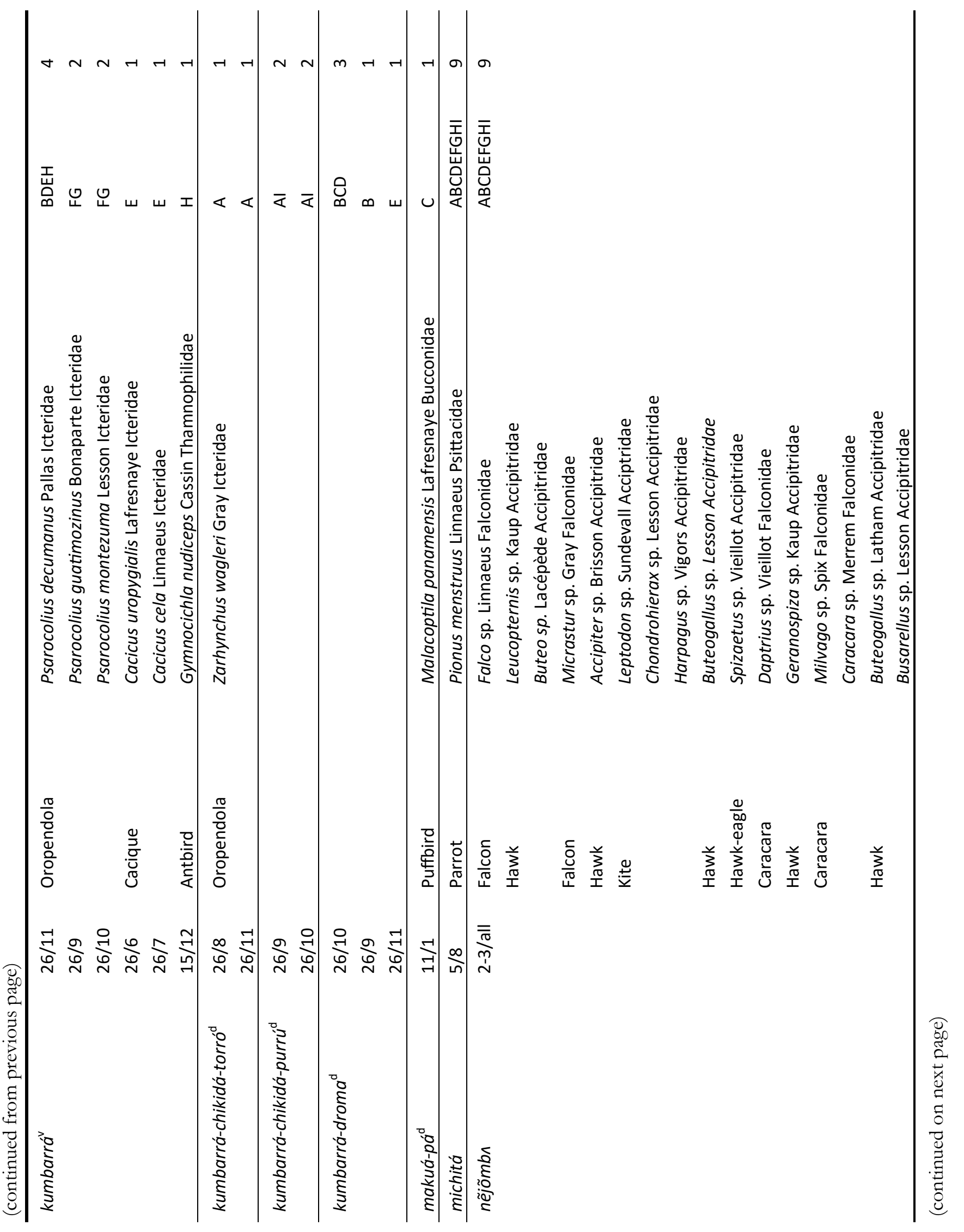

Ethnobiology Letters. 2015. 6:32-62. DOI: 10.14237/ebl.6.1.2015.226. 
fif Ethnobiolocy Letters Data, Methods \& Taxonomies

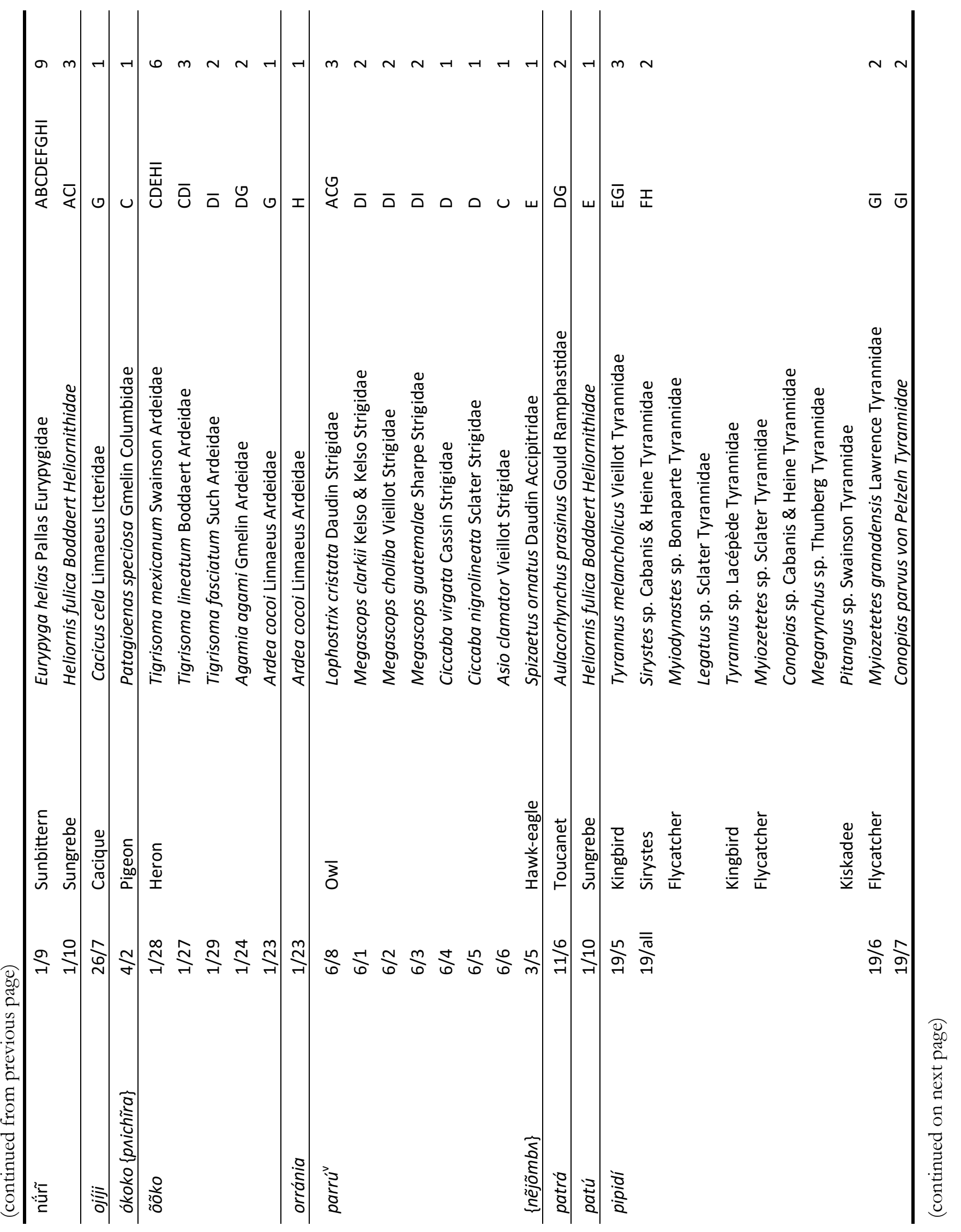

Ethnobiology Letters. 2015. 6:32-62. DOI: 10.14237/ebl.6.1.2015.226. 
(f) EthNOBIOlocy LetTers Data, Methods \& Taxonomies

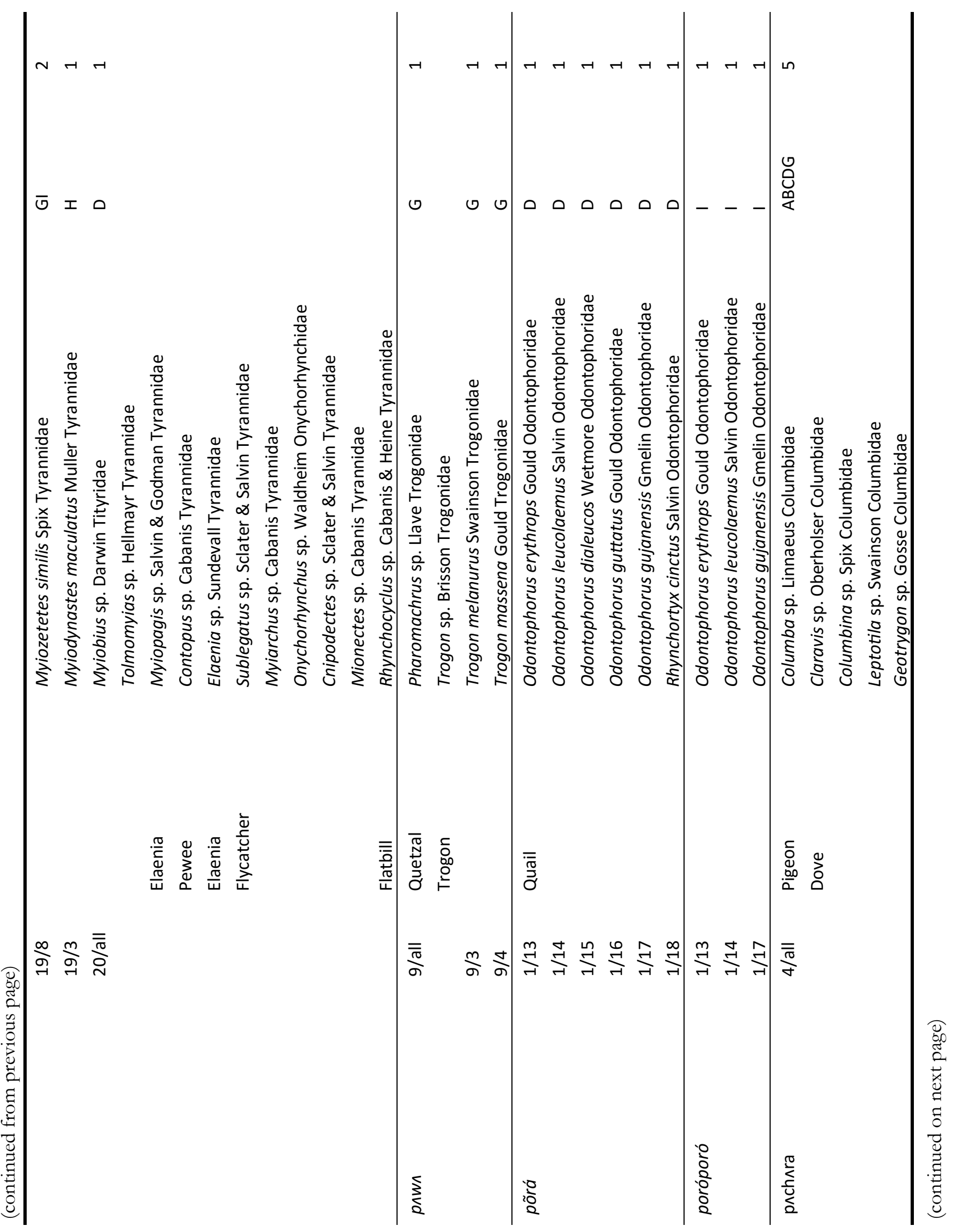

Ethnobiology Letters. 2015. 6:32-62. DOI: 10.14237/ebl.6.1.2015.226. 
fif Ethnobiolocy Letters Data, Methods \& Taxonomies

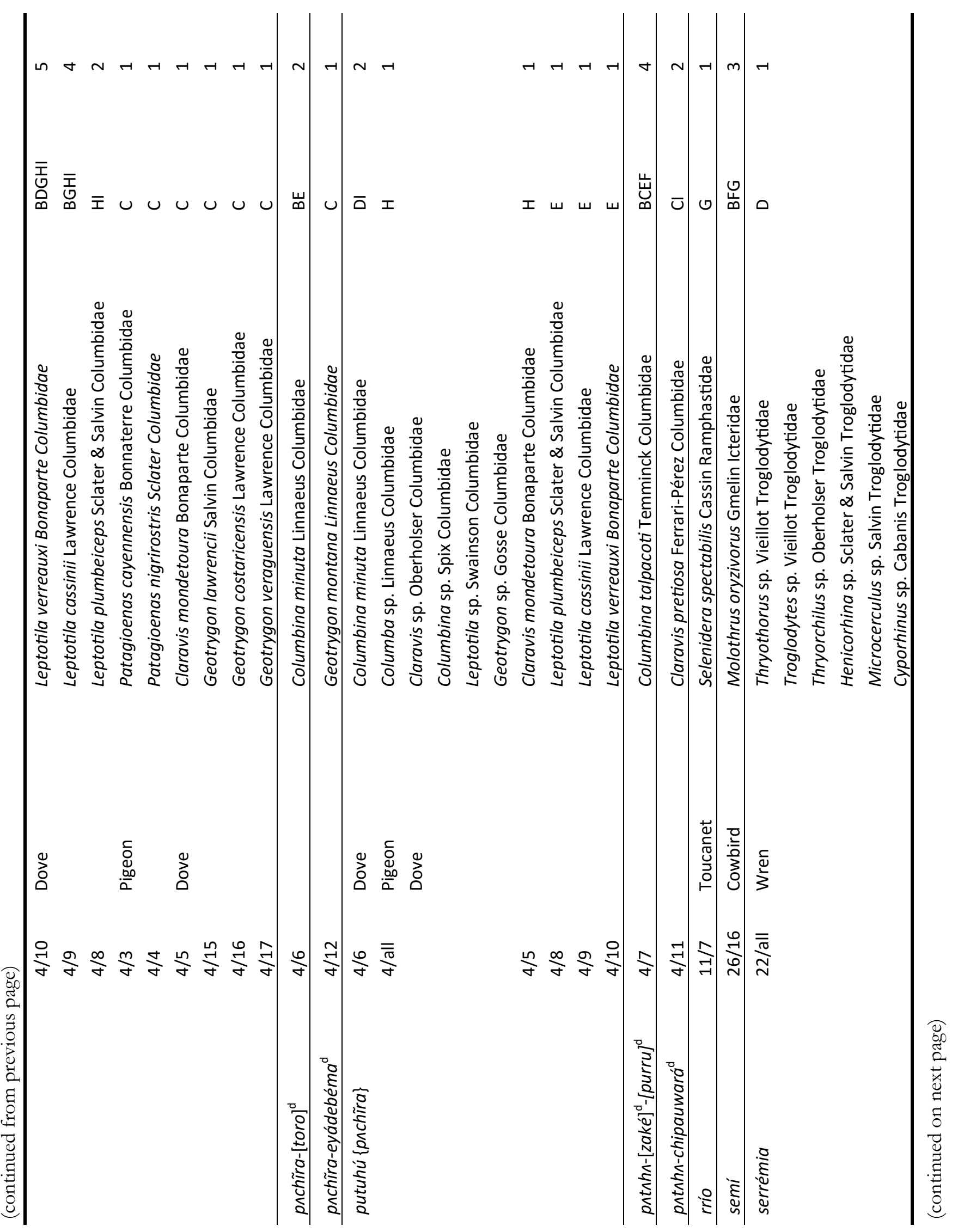

Ethnobiology Letters. 2015. 6:32-62. DOI: 10.14237/ebl.6.1.2015.226. 
fif Ethnobiolocy Letters Data, Methods \& Taxonomies

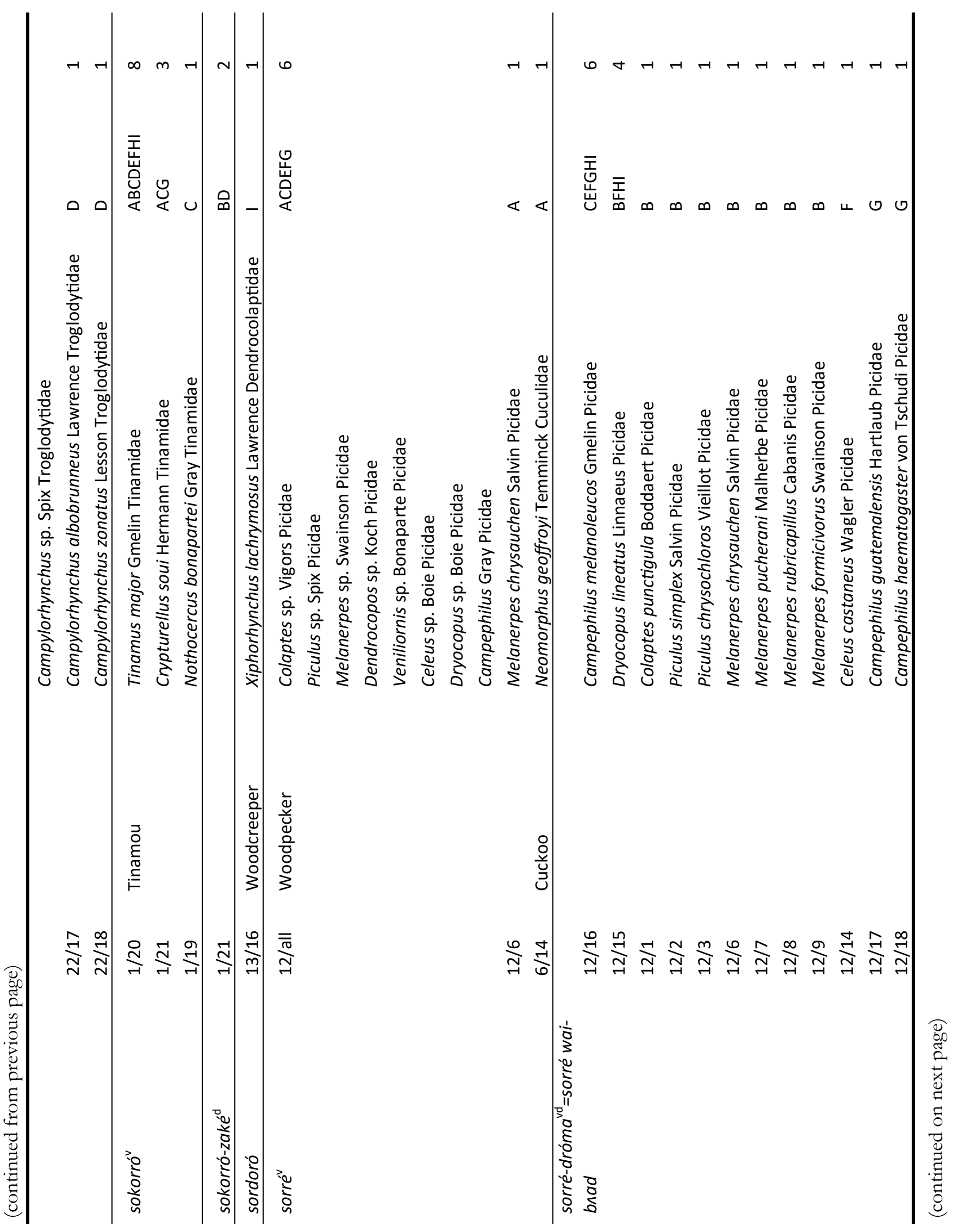

Ethnobiology Letters. 2015. 6:32-62. DOI: 10.14237/ebl.6.1.2015.226. 
(f) EthnObiolocy Letters Data, Methods \& Taxonomies

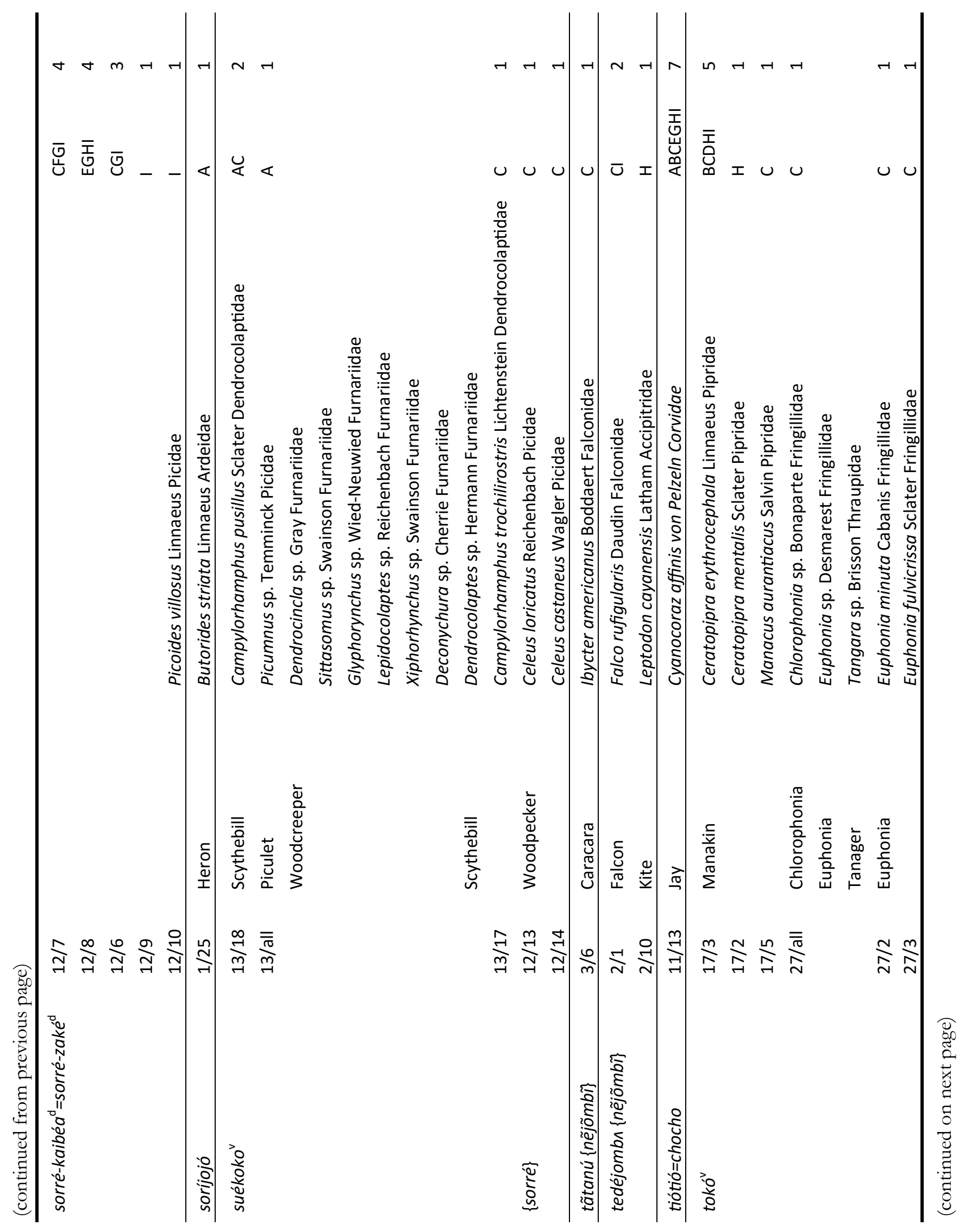

Ethnobiology Letters. 2015. 6:32-62. DOI: 10.14237/ebl.6.1.2015.226. 
Et) Ethnobiolocy Letters Data, Methods \& Taxonomies

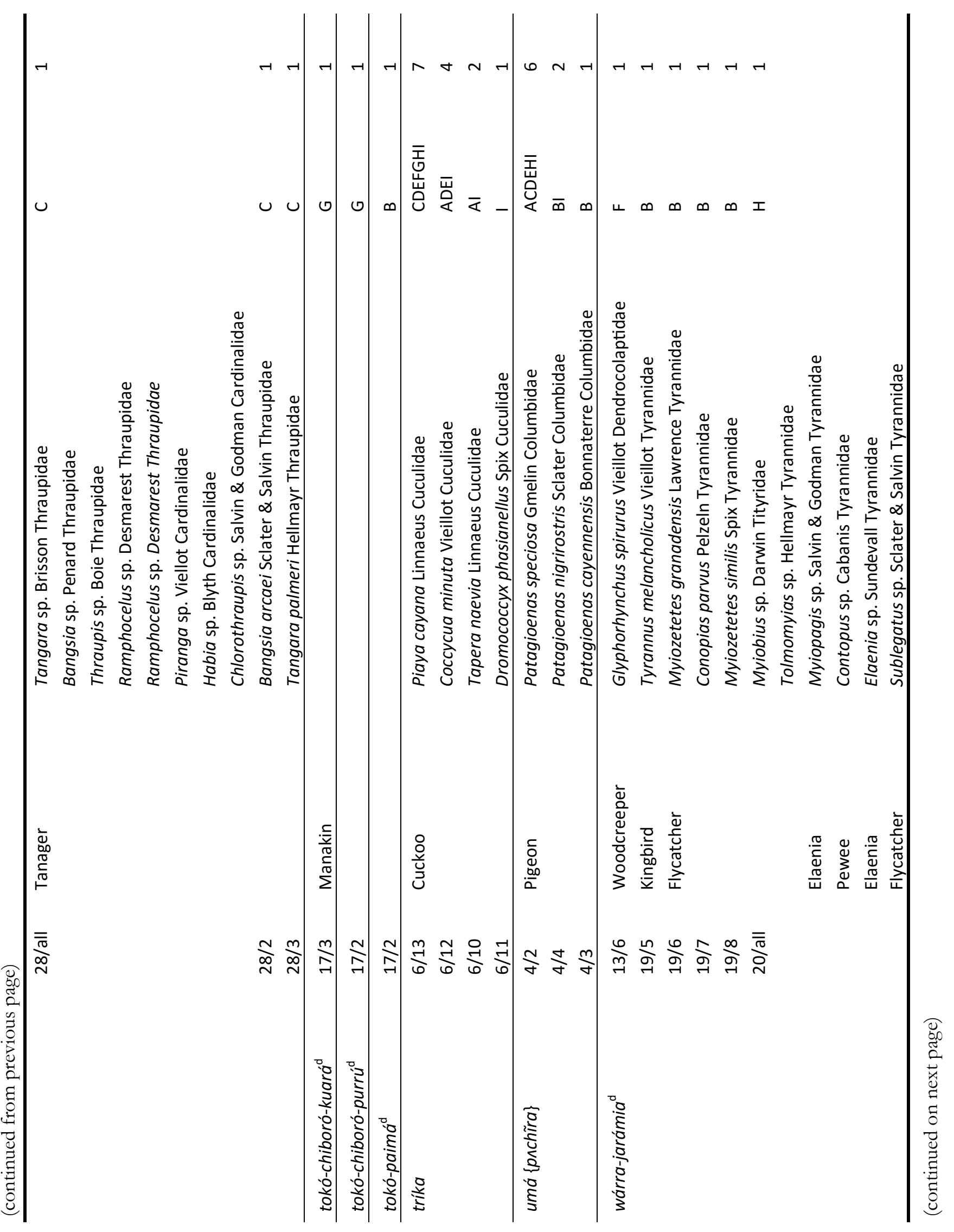

Ethnobiology Letters. 2015. 6:32-62. DOI: 10.14237/ebl.6.1.2015.226. 
EthNobiolocy LetTERS Data, Methods \& Taxonomies

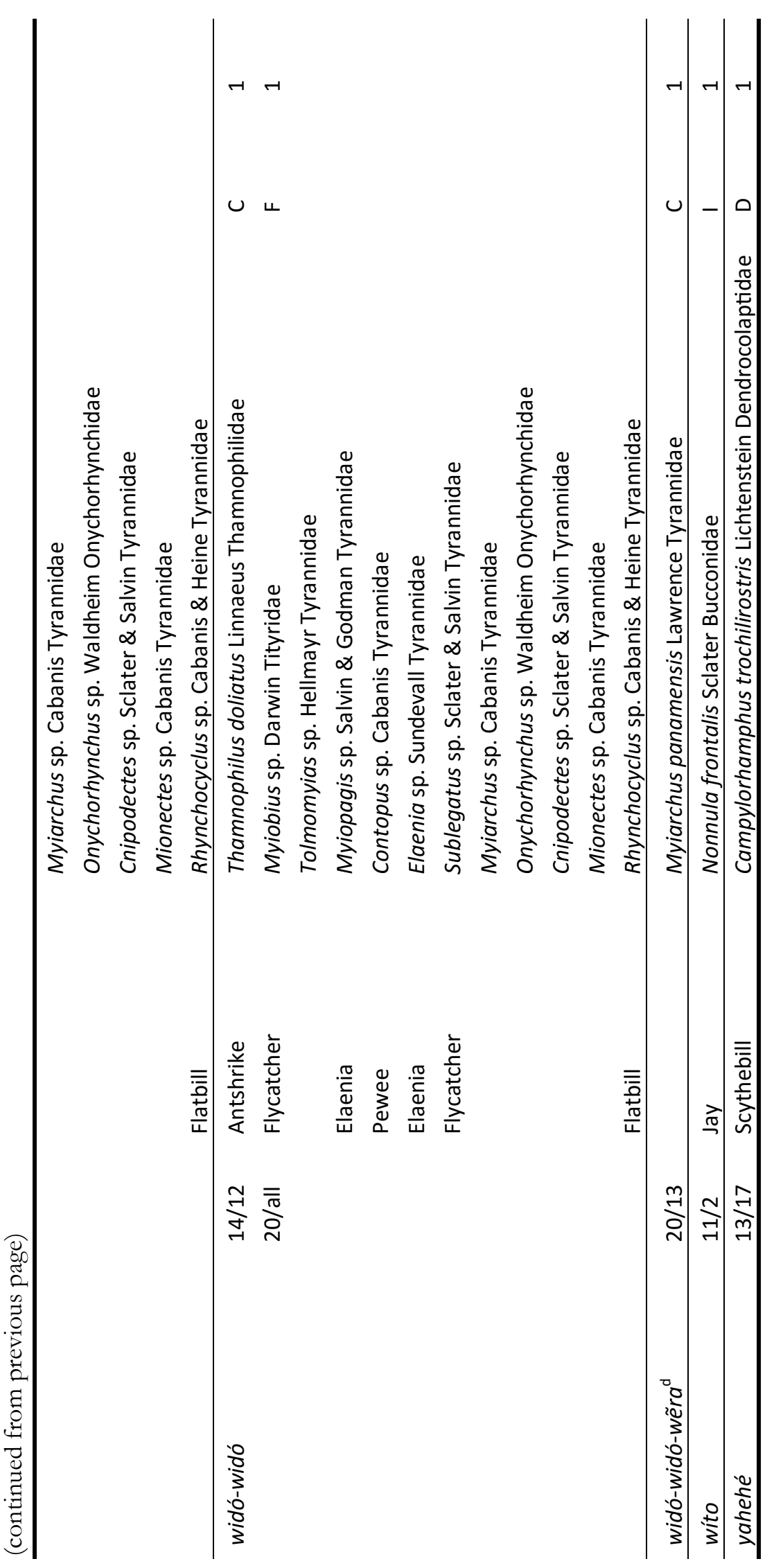

Ethnobiology Letters. 2015. 6:32-62. DOI: 10.14237/ebl.6.1.2015.226. 


\section{Appendix 2: Emberá Bird Folklore}

These data were collected either in the context of elicitation sessions or upon sighting or hearing the bird in a natural context. The information gathered in elicitation session is indicated with an "EC" after the bird name and that gathered in natural contexts with an "NC." See Appendix 1 for the scientific identification of Emberá bird names appearing in the text. Note however, the text includes some Emberá examples that I was not able to translate into scientific taxonomic categories in the elicitation sessions. Where I have been able to identify these by other means, or know the common Spanish name, I list them below.

The data are organized alphabetically by Emberá name within three categories: A) birds used in magic, B) birds used as symbols in folktales, C) birds whose songs and calls contain messages for the Emberá. Again, I include them here in order to bring the connotative and metaphorical meanings associated with names to the attention of the analyst. In general, compared to processes of denotative reference that are the basis of taxonomic naming, symbolic processes involved in the folkloric use of bird names tend to rely more on behavioral and functional attributes of the birds and less on morphological attributes. This could reflect the operation of different kinds of semantic processes, or is perhaps principally due to the fact that most of the folkloric data was collected in natural context.

Birds Used in Magic

antumiá (Sp. madre de agua, mother of waters) ${ }^{1}$

NC EC

Antumia is a malevolent spirit being of the night that Emberá conceptualize in various ways. It is most commonly associated with a clear, loud, whistling song composed of five long minor tones rising in pitch. (According to book descriptions, none of the birds identified in the elicitation sessions have this song. Interestingly, there was no consensus on any of the identifications.) The bird's eerie song comes out from the woods, is quite common and, in my experience, always evokes a strong reaction from Emberá listeners. I have been told that antumiá is a small black bird that is a messenger of the shaman (jaimbanâ). When shamans fight they send this bird out to kill. During the daytime it lives in the river, at night it walks around on land. However, not all
Emberá associate the song with a bird, or any other natural being.

cuervo (crow) NC

The crow's tail feathers were prescribed as treatment in a curing ceremony I attended for a little baby. The morning after the ceremony, a live crow was caught and its tail feathers were removed, then swept up and down over the child's body. Participants explained to me that this caused the baby to sweat profusely after which the sickness blew away.

dogowiru NC

The dogowiru is called the "Devil's chicken." Examples of relevant instructions follow below.

"If you catch it during Easter Week it brings good luck and money. You catch it on the night of Good Friday and take a walk on the beach. Then you pull out the tail feathers. The Devil will come up to you and in a deep, gruff voice demand, "Why have you killed my chicken? What do you want?" And, if your heart is strong, you say, "I want money," and the Devil will deliver it to you."

domiá and choribú (2 kinds of sandpipers) Scolopacidae NC

"Dios dejo domiá muy puta (Sp. God left domiá like a whore [God upset domia])," says my informant, bumping and grinding his behind side to side, bending at first one knee then the other, mimicking the tail movements of this bird when it walks. "So," he says, "if your lover humiliates you by taking other lovers, take the tail feathers of domiá and, when your lover is sleeping, put them between the big and the second toe and move it up and down, in and out, chanting "Auduobaya jumaraba nonia" (Go with all). After that your lover will be compelled to have sex with dogs, animals, anything that walks."

makuá-pa and bidó-koróchia EC NC

These birds are both used to do makuá, a magical practice that men and women do to attract individuals for various purposes. Most commonly, individuals do makua to attract another person of the opposite sex. One can also do makuá to start up some business, like a store or canteen. It will then call people away from competitors. To do it, one makes a potion made of various ingredients, such as feathers of these birds. Another animal that can be used is a little arthropod (coropipi) that 
lives on the riverine beaches and climbs into sand holes backwards. There are also plants called makuá that are usually scented sweetly. People may even use bottled perfume. Once the potion is made, it is put on while chanting some appropriate words. If a man is after a woman, when she walks by him while the magic is in effect, she cannot pass him by. This practice is not specific to Emberá. Indeed, I saw a sign for makuá in the market of Panama City.

sorré (woodpecker) EC NC

The woodpecker is essential to the magical acquisition of good axmanship. What you need to do first is get a hold of a large male sorré. This is the bird that can make a hole in a thick, hard tree by repeatedly hitting the same spot, fast and precisely with his beak. He will go and go. If the hole is not made at once he will keep going till he is finished. The first time I heard about this was in the course of observing the construction of a dugout canoe, a process in which there is no room for inexpert ax handlers. The trick, when starting the job, is to hit hard along a certain angle so the wood can be cut out in large blocks. To do the smooth finishing at the end, hit the sides with fine precision. Great strength and several people are required to sustain ax work for the long hours that stretch into weeks of canoe construction.

So you get a sorré, grate its beak and mix it with jagua (the blue black dye from Genipa americana L. Rubiaceae). Then paint it on your hands, quickly rubbing up and down first one then the other, while repeatedly chanting something to the effect of, "Leave me strong like you."

This magic is done when the moon is full, just rising on the horizon. It is done four times in a man's life, at no specific age.

"It can be done the first time as a boy," my informant says as he points to his six and eight year old sons. "But it can't be done more than four times because then you become too strong."

Too much strength is also no good. You can ruin a canoe like that. However, when a man uses this magic correctly, he is stronger and better at wielding an ax. If you put him side by side with the man who has not done it, the one with magic wins any contest of strength. He can finish taking out the innards of a $\log$ by noon.

When the sorré is making a hole his cry is,
“Trrrrrrrrr-ke-ke-ke-ke," just like people when they are working. Whenever men are working hard with an ax or machete they cry out when the work gets most intense. There is a variation of this method in which the powdered beak of sorré is put in the bellybutton of male newborns.

\section{Birds Used as Symbols in Folktales 2}

While traveling downriver one morning in the dry season on our way to a regional political meeting, my companions could not pass up the numerous female opogá (Iguana iguana L. Iguanidae) basking in the sun up on the branches of leafless Cecropia trees (eborró). After they cut down the trees with machetes and tried to grab the iguanas as they fell into the river, capturing one and missing two, they decided to send someone back to the village to get a rifle. While we were waiting I was told all but two of the folktales that follow below. The ones about kumbarrá and sorré were told in other contexts.

angosó (vulture) NC

Dzoshua, a village elder, points up to the angosó

flying high in the distance and says, "He's always looking for the dead."

His daughter Zelda interrupts, "That brings luck. Ask the angosó for luck while hunting because he likes dead animals."

Then Dzoshua tells this tale: "One day angosó finds a cow lying there in the forest. He walks around it, examining it carefully. He walks up to the head and looks in the eyes. Is it dead? He wonders. The eyes are closed. Yes, well, it must be dead. So he sticks his head in the cow's anus. Thinking the cow was dead, he sticks it in so far his beak comes out of the mouth end. But then, the cow tightens up his anus and angosó can't get out! It wasn't dead after all. Finally angosó manages to pull his head out, but he was left bald. And that's why angosó has no feathers on top."

ansabidá (kingfisher) NC

Getting impatient, Dzoshua walked over complaining how the iguanas (opogâ) always deceive man by getting away all the time. To make us all feel better he reminded us about the tale in which ansabidá deceives opogá:

Opogá asks ansabidá, "Could you warn me if any people come downriver? I want to lie out here in the sun and snooze on this tree for a while." 
So opogá stayed sleeping on this tree. [Dzoshua mimes the iguana lying on the side of the tree trunk on the side away from the river.] When all of a sudden he spotted people in a canoe coming downriver! Realizing ansabidá had lied to him, he watched, staying very still, peeking carefully around the edge of the trunk.

And then the cholo (Indian) in the canoe calls, "Opogal On the tree!"

"Oh shit!" says opogá and falls into the water.

And the Indian cries, "Get him! He's full of eggs!"

Then lunging for the opogá, he catches him and kills him.

Note that the inedible kingfishers, small and large, are some of the most common and noticeable birds on the river. Their rapid flight diagonally across the water can be seen at all seasons. Here is another tale in which the oropendola, probably Psarocolius decumanus Pallas Icteridae, which Ridgely (1976:306) mentions often nests in Cecropia trees, also tricks iguana. It was told to me while I watched Dzoshua constructing a canoe by the river's edge.

kumbarrá (kingfisher) NC

And then there is kumbarrá, the black bird with a red patch that cries out loudly as he falls from the sky towards the water. Poor opogá took fright, for he thought kumbarrá was falling into the river. But kumbarrá only laughed. He was only playing.

Still waiting on the beach, Dzoshua's daughter Zelda continued telling me folktales. The next one is as close to a creation story as I've heard from the Emberá. The heroes or, rather, anti-heroes, are woodpecker and the crowned lizard (Basiliscus basiliscus L. Corytophanidae). (ochorró in Emberá). Sometime before this I had learned that, like the woodpecker, the crowned lizard was an axman in ancient times when animals were people. He was in the middle of an ax swing when the world changed. The ax got fixed to the top of his head and because it is quite heavy, ochorró cannot run very far on water. Astonishing enough to a newcomer in the tropical forest, Basiliscus does really run across small streams.

sorré (woodpecker) NC Zelda said, "And there was sorré and ochorró. They were stealing water from the epave tree [Anacardium excelsum Bertero \& Balb. ex Kunth Anacardiaceae] and God knew it.

So God asks them, "Oh, by the way, where did you get that water from?"

Knowing full well where they got it, they kept their mouths shut. What could they say, after all? Then God got mad and made the epave tree burst open. [Zelda interrupted her telling to gesticulate animatedly, flinging her arms up into the air and stretching them in various directions.] Woosh, woosh, woosh, the water burst all over, making rivers and big lakes. Each branch (of the tree) became a river. And so sorré and ochorró stayed with their axes on their heads."

I include one last folktale here, told to me by Dzoshua in his house, to illustrate the use of bird imagery in the discussion of contemporary problems.

sokorró (tinamou) (Tetrao major Gmelin Tinamidae) NC Dzoshua said, "Well you know how come we Indians never have any money? It's like this: "We cholos (Indians) grab the sokorró (our chicken) by the tail feathers and of course, what happens? The feathers pull out and the bird gets away. And the same with deer. We grab it by the tail and the tail breaks off. And the cow and the horse too. But no, not the kampuniá (non-Indian). The kampuniá grabs it by the hoof and it can't get away. Then he puts it away to breed so he can keep it. Like money. But the cholo? Thirty dollars, fifty dollars, one hundred dollars-eaten. [Dzoshua makes a hand to mouth movement.] But not the kampuniá: he's got one hundred dollars and suddenly he's got more."

Birds Whose Songs and Calls Contain Messages for the Emberá

bidó jarámia $\mathrm{EC}$

This bird's name speaks for itself: "a being that tells of white-lipped peccary" (Tayassu pecari Link Tayassuidae). In other words, the appearance of this bird signals the proximity of one or more white-lipped peccaries, which are an important source of meat.

dogowiru (kind of nightjar) possibly Nyctidromus albicollis Gould Caprimulgidae NC

This crepuscular and nocturnal ground nester, whose name iconically mimics its song, advises when the new moon appears and when there is a 
clear moon. They say it has a house of moonlight (jedeko debema). Through its oft repeated song this bird musically says, "Estoy jodido. No tengo sabana (I'm screwed. I have no sheet)."

Known as the Devil's chicken, the dogowiru is a magical counterpart of the Emberá's chicken, the edible tinamou known as sokorró.

During the elicitation sessions several people noted that the dogowiru was not among the birds illustrated in the plates. Because the bird's song is the most salient, culturally familiar aspect, this may mean that they do not recognize the bird's image among the nightjars, or alternatively, that the dogowiru is not a nightjar.

do-miá (kind of sandpiper) Scolopacidae NC

This is a little seabird that often frequents the rivers of Darién. Since ancient times the old people have known that, when they see this little bird walking along the riverbanks, the river will rise.

eteré umákira (rooster) Gallus gallus domesticus L.

Phasianidae NC

When an eteré umákira (literally, "chicken of the male sex") crows, they say he is trumpeting in Spanish, "Jesu Cristo nació (Jesus Christ was born)."

A white rooster also symbolizes the character of Jesus in folktales in Central and South America more broadly.

jue jué $\mathrm{EC}$

This bird's song tells of the presence of collared peccary (Tayassu tajacu L. Tayassuidae).

kué-dredrémia EC

This bird, who is considered to be a rain being, advises of coming rain.

kué-trumia EC

The name literally means "being that tells of rain." The Emberá say that when a hard rain is going to fall this bird is happy. It dances and sings "pi-pi."

Kué-trımia is listed in appendix as a chingé of central importance.

serrémia $\mathrm{EC}$

This bird may also be referred to as wio wio, which means "Good day" in Emberá. This is the happy sound it makes when it is going to rain. suenrú (Sp. corni) NC

This is the little bird that tells time. It sounds at dawn, at 3:00 PM and again at 4:00 PM. The fact that suenru sings at dawn and in the day is significant because it distinguishes this bird from the similar night song of the fearsome antumiá.

wáko (laughing falcon) Herpetotheres cachinnans

L. Falconidae EC

This bird calls out in Spanish, "Cafe con harina (coffee and flour [dough cakes])." These foods are the preferred food for wakes and the bird's call signals that someone is about to die. This bird was identified from a black and white drawing in the same book that I used for the photo elicitations. Ridgely (1976:77) describes the species as having far-carrying calls, most often a loud, "Guaco, gua-co." Note that if you pronounce this verbal rendition of the call it sounds almost identical as the Emberá name.

wárra-jarámia $\mathrm{EC}$

This name literally means "being who tells of child." The Emberá say that when a woman becomes pregnant this bird tells them. When two birds are seen walking together and the male follows the female, the baby will be a girl. If the female follows the male, the baby will be a boy.

widó-widó EC

This bird advises you at the very beginning of pregnancy. Even if you deny being pregnant, this bird will tell.

\section{References}

Ridgely, R. 1976. A Guide to the Birds of Panama. Princeton University Press, Princeton, NJ.

\section{Notes}

${ }^{1}$ Widespread folklore of Mother of Waters originated in Africa. See for example Drewal 2008.

${ }^{2}$ Note that these tellings happened spontaneously in situ and I had no tape recorder. These versions are composed on the basis of rough notes. Analysis of the following tales are available in the context of ethnographic description and analysis. See Kane (1994/2004:66-82) for woodpecker tales and canoebuilding. See Kane 1994/2004:23-5 for iguana hunting and vultures on the way to a political congress. For a creation story see Kane 1994/2004:20. 